Williams v. Rhodes: How One Candidate, One State, One Week, and One Justice Shaped Ballot Access Law

Eren Jon Alexander Gryskiewicz Alexandria, Virginia

J.D., University of Virginia, 2013

A.B., Georgetown University, 2008

A Thesis presented to the Graduate Faculty of the University of Virginia in Candidacy for the Degree of Master of Arts

Department of History

University of Virginia August, 2013

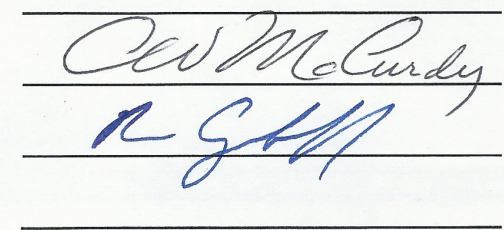




\section{Williams v. Rhodes: How One Candidate, One State, One Week, and One Justice Shaped Ballot Access Law}

\section{INTRODUCTION}

In 1968, the Supreme Court broached a new field of constitutional law when it decided Williams v. Rhodes. Faced with popular Alabama Governor George Wallace's challenge to Ohio's complex and restrictive ballot access laws, the Court ordered him onto the ballot. The opinion's rationales had far-reaching implications and produced complicated jurisprudence. It was a signpost to nowhere, and the Court has been trying to find the right direction since, attempting to massage coherence into its ballot access jurisprudence by employing different rationales and scrutiny levels. This Note describes and explains the political, historical, and legal factors impacting the Williams decision. Since Williams, the Court has used the Equal Protection Clause and the First Amendment; strict, intermediate, and rational basis scrutiny; a balancing test; and a system incorporating all of this accumulated flotsam less the Equal Protection Clause. This jurisprudence has left unclear instructions to lower courts. The Court should remedy this confusion by picking a single standard with prudent legal rationales and sound historical bases.

The political environment of 1968 and Ohio's anti-democratic legal framework compelled the Justices to place Governor Wallace on the Ohio ballot. Wallace's campaign represented a national movement. Denying his supporters the chance to vote for him would have been political folly, and Ohio's laws kept all but the Democratic and Republican parties from the ballot, which forced the Court's hand on the issue. But the Court's first foray into the field of ballot access law created a jurisprudential obstacle course that the Court has contorted its way through since 1968. As a result, today's judges are left to pick between two standards or to apply both, resulting in confusion and post hoc rationalization. This Note uses the Justices' papers to illuminate the Court's internal debates from Williams through its landmark cases, demonstrating dissonance between the Justices and revealing discarded doctrines. Finally, this Note argues that the test set forth in Anderson v. Celebrezze coupled with a focus on the entire statutory scheme, as observed in Williams, provides the historical foundation and jurisprudential solution to the problem of ballot access law.

This Note has five parts. Part I provides an examination of the political climate of 1968 with an emphasis on Wallace's unique candidacy and its impact on the Court. Part II describes the history of ballot access laws in America and Ohio and illustrates Ohio's outlier status. Part III follows the opinion's development from conference to publication using internal memoranda to explain that process. Part IV outlines the Williams decision and its opinions. Part V uses Court papers and opinions to examine the Court's 
subsequent handling of Williams and the Court's search for a standard. It demonstrates that two standards remain in ballot access law. This Part concludes with an analysis of the impact Williams and its progeny have today, using a 2012 case, and proposes an explicit adoption of the test set forth in Anderson v. Celebrezze, with a focus on the whole statutory scheme. The article ends with a brief conclusion.

\section{George WALLACE \& THE 1968 CAMPAigN}

1968 was a year of turmoil in America. Racial tension, the Vietnam War and President Johnson's withdrawal therefrom, and the assassinations of Senator and presidential candidate Robert Kennedy and Dr. Martin Luther King, Jr. exploded America's collective conscience and any vestigial veneer of political stability. And while Vice Presidents Richard Nixon and Hubert Humphrey vied for the presidency, Governor George Wallace launched an independent bid from the Deep South. This Part examines the Wallace presidential campaign and his turn to the Court.

\section{A. The Wallace Campaign}

Governor Wallace, despite his repugnant segregationist views, was not a fringe candidate. Indeed, he seemed to have a "gut knowledge of the prejudices of the lowincome class," "with considerable support across the nation. In fact, in a September 29 Gallup poll, Wallace garnered $21 \%$ of the likely vote, merely seven percent behind Hubert Humphrey. ${ }^{2}$ On election day, he collected nearly ten million votes, almost $13.5 \%$ of the popular vote, and won five southern states for forty-five electoral votes. ${ }^{3}$ It was the best showing for a third-party candidate since Theodore Roosevelt in $1912^{4}$ and bested the thirty-nine electoral votes on $2.4 \%$ of the popular vote then-Governor Strom Thurmond's 1948 campaign received. ${ }^{5}$ Wallace also topped Thurmond in the North, garnering eight percent of the vote outside of the South, compared to Thurmond's less than one percent. ${ }^{6}$ Chart 1 below compares third-party candidates and their electoral

1 Dan T. Carter, The Politics of Rage: George Wallace, the Origins of the New CONSERVATISM, AND THE TRANSFORMATION OF AMERICAN POLITICs 367 (1995). He also raised over nine million dollars for his campaign, including \$30,000 from John Wayne, who wrote "Sock it to 'em, George," on his last check. Id. at 335, 338.

2 Bradley Smith, Judicial Protection of Ballot-Access Rights: Third Parties Need Not Apply, 28 HARV. J. ON LEGIS. 167, 180 n.71 (1991).

3 The Election of 1968, THE AMERICAN PRESIDENCY PROJECT, http://www.presidency.ucsb.edu/showelection.php?year=1968 (last visited Oct. 15, 2012).

4 The Election of 1912, THE AMERICAN PRESIDENCY PROJECT, http://www.presidency.ucsb.edu/showelection.php?year=1912 (last visited Oct. 15, 2012).

The Election of 1948, THE AMERICAN PRESIDENCY PROJECT, http://www.presidency.ucsb.edu/showelection.php?year=1948 (last visited Oct. 15, 2012).

${ }^{6}$ Carter, supra note 1 , at 369. 
success, with Wallace's electoral and popular vote percentages illustrating his significant support.

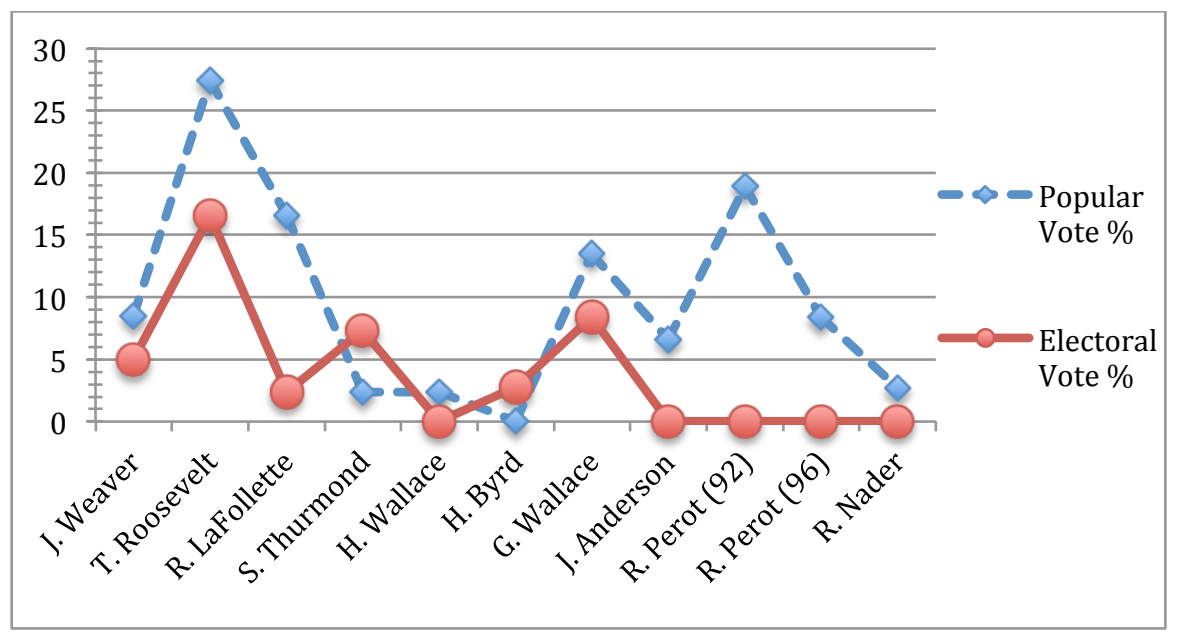

\section{Chart 1: Electoral and Popular Vote Percentages of Third Party Presidential Candidates $^{7}$}

In Ohio, after the Court ordered him on the ballot, Wallace received 467,495 votes, around five percent of his national total and well behind Nixon's 1,791,014 and Humphrey's $1,700,586 .^{8}$ Nonetheless his total was significantly greater than the gap between the major party candidates and well above any write-in candidate, the highest of whom received 372 votes. ${ }^{9}$

The Wallace campaign, therefore, represented a strong political force. His high polling numbers and millions of votes received demonstrated the seriousness of his challenge. ${ }^{10}$

\footnotetext{
${ }^{7}$ See William Graf, Statistics of the Presidential and Congressional Election of November 2, 1948 48-49 (1949); Presidential Elections Data, THE AMERICAN PRESIDENCY PROJECT, http://www.presidency.ucsb.edu/elections.php (last visited Oct. 15, 2012). Although I have not included unfaithful electors in general, I have included Harry Byrd's 15 electoral votes in 1960, which came from unpledged electors in Alabama and Mississippi and a faithless Oklahoma elector. Historical Election Results, Electoral College Box Scores 1789-1996, U.S. ElECTORAL COLLEGE, http://www.archives.gov/federal-register/electoral-college/scores.html\#1960 (last visited Nov. 18, 2012). Wallace's electoral showing vis-à-vis LaFollette and Perot is a result of his concentrated Southern support.

81968 General Election Overview, OHIO SECRETARY OF STATE, http:/www.sos.state.oh.us/SOS/ elections/Research/electResultsMain/1960-1969Results/68overview.aspx (last visited Oct. 15, 2012).

${ }^{9}$ Id. Write-in vote totals were: Dick Gregory 372, Henning A. Blomen (Soc. Labor) 120, Fred Halstead (Soc. Workers) 69, Charlene Mitchell (Communist Party) 23, and Earle Harold Munn Sr. (Prohibition) 19. Id.

${ }^{10}$ Presumably more Americans agreed with the principle that Wallace should appear on the ballot. In a letter to Justice Hugo Black, Charles A. Davidson of Starke, Florida wrote that he would not vote for Wallace but that the Court had to protect him in the name of American democracy. Letter from Charles A. Davidson to Justice Hugo L. Black (Oct. 17, 1968) (on file in the papers of Hugo L. Black). Mrs. Carl R. Killman agreed. Letter from Mrs. Carl R. Killman to Justice Hugo L. Black (Oct. 16, 1968) (on file in the papers of Hugo L. Black). Mr Warden Downs put it bluntly: "to refuse George Wallace and Curtis Lemay
} 
This evidence suggests that a strong national tide in support of a Wallace candidacy rose upon the Court in October 1968, pushing it toward the Williams result. To disenfranchise so many Ohioans would have been politically tone-deaf.

\section{B. Getting to the Court}

Wallace's journey to the Court began January 1968 when the American Independent Party (AIP) formed in Ohio. ${ }^{11}$ The party spent the next six months collecting the 433,100 signatures needed to access the ballot. ${ }^{12}$ However, the AIP missed the deadline to submit signatures, which it mistook to be ninety days before the general election, rather than the primary election. ${ }^{13}$ The Party brought suit in the Southern District of Ohio on July 29, 1968 , praying for relief and ballot access. ${ }^{14}$

In the companion case, the Socialist Labor Party (SLP), a minor but old Ohio party, also sued, seeking placement on the ballot and asking that the District Court invalidate Ohio's ballot access laws. ${ }^{15}$ Unlike the AIP, the SLP had the formal attributes of a party, as Ohio law required: it held conventions and formed a state committee. ${ }^{16}$ It did not, however, have the AIP's popular support, numbering only 108 Ohioans. ${ }^{17}$

A three-judge District Court panel combined the cases and granted partial relief, finding that the prohibition against write-in ballots denied voters equal protection and requiring Ohio to provide a space for write-in votes, but refusing ballot placement for either party. ${ }^{18}$ The AIP, the court reasoned, was barred by laches, and the SLP had delayed its suit and was too small to warrant complete relief. ${ }^{19}$ The AIP quickly appealed; the SLP did not. Justice Stewart, as Circuit Justice for the Sixth Circuit, stayed the AIP decision and placed Wallace on the ballot, pending a successful challenge in the Supreme Court. ${ }^{20} \mathrm{He}$ denied the same relief to the SLP, which did not bring its own appeal until after Justice Stewart's AIP ruling - threatening delay that would derail Ohio's election

on the Ballot is to refuse five hundred thousand voters there right to vote in Ohio . ..." Letter from Mr. Warden Downs to Justice Hugo L. Black (Oct. 8, 1968) (on file in the papers of Hugo L. Black).

${ }^{11}$ Williams v. Rhodes, 393 U.S. 23, 26 (1968).

${ }^{12}$ Id.; Brief for Appellants at 17, Williams v. Rhodes, 393 U.S. 23 (1968) (No. 543), 1968 WL 129460, at $* 17$. They ultimately collected 452,867 signatures.

${ }^{13} \mathrm{Id}$. at $* 6$.

${ }^{14}$ Id.

${ }^{15}$ Williams, 393 U.S. at 34.

${ }^{16} \mathrm{Id}$. at 27.

${ }^{17} \mathrm{Id}$. at 28 .

${ }^{18}$ Socialist Labor Party v. Rhodes, 290 F. Supp. 983, 987, 990 (S.D. Ohio 1968); see also Williams, 393 U.S. at 27-28. The specifics of Ohio's ballot access laws are discussed in Part II, infra.

${ }^{19}$ Williams, 393 U.S. at 27-28.

${ }^{20}$ Williams v. Rhodes, 89 S. Ct. 1, 2 (1968) (order granting preliminary injunction) ("[I]n the absence of a temporary order by me at this time, difficult if not insurmountable practical problems in the preparation of ballots would result, should the judgment of the United States District Court be reversed by this Court."). 
processes. ${ }^{21}$ Justice Stewart scheduled oral arguments for October 7, 1968 - the first day of the new term, with the election less than a month away.

\section{The Opinion}

In its first foray into a traditional state sphere, ${ }^{22}$ the Court struggled to find its way among the many implicated Constitutional provisions. After 1948, Ohio erected a ballot access system designed to entrench the Democratic and Republican parties. Ohio banned independent candidates and required new parties to collect signatures totaling fifteen percent of the votes cast in the last gubernatorial election, to present these signatures three months before the primary election, and to establish party structures. ${ }^{23}$ The Court held that the laws in their totality violated the Equal Protection Clause and ordered Governor Wallace onto the ballot. ${ }^{24}$

The opinions can be summarized as follows: Justice Black for the Court (Fortas, Marshall, and Brennan) applied a strict scrutiny analysis under the Equal Protection Clause; Justice Douglas concurred, rooting his opinion in the First Amendment; Justice Harlan also concurred, finding the parties' First Amendment rights had been violated under the Due Process Clause; Justice Stewart dissented, arguing that states enjoyed substantial powers in the selection of presidential electors, but that the Equal Protection Clause - tempered by a rational basis test - did apply; Justice White, also dissenting, believed the state had the powers to act as it had and that the AIP and SLP had failed in their duty to comply with the statutes; and Chief Justice Warren dissented on the grounds that the opinion was rushed, given its implications. The Note will more fully examine the opinions in Part IV, but for now turns to the history of ballot access laws in America.

\section{From Protection to ExClusion: BALLOT ACCESS HistORY IN THE U.S. \& OHIO}

\section{A. Ballot Access in America}

The official ballot and its concomitant regulation have resulted in a proliferation of rules designed to keep the Democratic and Republican parties on and third parties and independents off the ballot. This section examines the development of the official ballot, state regulations of that ballot, and the impetuses for such regulation up to 1948, when the focus shifts to Ohio.

\footnotetext{
${ }^{21}$ Williams, 89 S. Ct. at 3; Williams, 393 U.S. at 28.

${ }^{22}$ See infra Part II.

${ }^{23}$ See infra Part II.

${ }^{24}$ Current and contemporary commentators attribute the equal protection analysis to the Court's reapportionment cases, where it established the one-man, one-vote principle. See, e.g., Todd J. Zywicki, Federal Judicial Review of State Ballot Access Regulation: Escape from the Political Thicket, 20 T. MARSHALL L. REV. 87, 127-29 (1994).
} 


\section{The Rise of the Official Ballot}

Official ballots developed after a century of American voting. ${ }^{25}$ The first American elections were public affairs "conducted orally or by a showing of hands. ${ }^{.26}$ Without privacy, intimidation and bribery proliferated, necessitating paper ballots. ${ }^{27}$ The first ballots were unofficial, private creations, which voters were expected to submit at the polls. ${ }^{28}$ Seizing the opportunity, parties began producing colored ballots with partisan slates, which, by their singularities, signaled one's vote, thereby eliminating voter privacy. ${ }^{29}$ The system, in effect, returned to public elections: bribery and intimidation returned $^{30}$ and ballot stuffing emerged. ${ }^{31}$

As private solutions failed, states adopted the Australian, or secret, ballot - an official, state-controlled solution developed to combat intimidation and fraud in Australia. ${ }^{32}$ By the end of 1888, Louisville, ${ }^{33}$ Massachusetts, ${ }^{34}$ and New York had adopted it. ${ }^{35}$ By 1893 , the number had grown to thirty-five states. ${ }^{36}$ Although the official ballot reaffirmed voter privacy, it raised a new problem: it required regulation. Devices had to be created to determine who and what would appear, ${ }^{37}$ as states sought to prevent overcrowding ${ }^{38}$ and voter confusion. ${ }^{39}$ Professor Floyd Mechem put it well in 1904, writing: "It is only when

\footnotetext{
${ }^{25}$ Oliver Hall, Death by a Thousand Signatures: The Rise of Restrictive Ballot Access Laws and the Decline of Electoral Competition in the United States, 29 SeattLe U. L. REV. 406, 417 (2005); Smith, supra note 2, at 172; Adam Winkler, Voters' Rights and Parties' Wrongs: Early Political Party Regulation in the State Courts, 1886-1915, 100 COLUM. L. REV. 873, 876 (2000).

${ }^{26}$ Hall, supra note 25 , at 416.

${ }^{27}$ Id. at 417.

${ }^{28}$ Id. at 417; John W. Epperson, The Changing Legal Status of Political Parties in the United STATES 81 (Harold Hyman \& Stuart Bruchey eds.,1986).

${ }^{29}$ Hall, supra note 25, at 417; Smith, supra note 2, at 172.

${ }^{30}$ Hall, supra note 25, at 417; Smith, supra note 2, at 172.

${ }^{31}$ EPPERSON, supra note 28, at 82; Smith, supra note 2, at 172.

${ }^{32}$ Hall, supra note 25, at 417; Smith, supra note 2, at 172-73 ("The Australian ballot was praised as a device that would open up the two-party system to challenge by third parties. It was hoped that the secrecy of the ballot would not only prevent bribery and outright intimidation, but also the subtler sanctions of ridicule, dislike, and social or commercial injury. As a result, the Australian ballot would break political machines and allow new political competitors to compete on more equal terms with established parties.").

${ }^{33}$ EPPERSON, supra note 28, at 82.

${ }^{34}$ Id.; Hall, supra note 25, at 417; Smith, supra note 2, at 172; Nicholas Walstra, Comment, Consistently Unconstitutional: Examining Ohio's Ballot Access Laws, 38 CAP. U. L. REV. 109, 111 (2009).

${ }^{35}$ Hall, supra note 25 , at 417.

${ }^{36}$ EPPERSON, supra note 28, at 82. Smith has complementary data, noting that "[b]y 1900, thirty-nine states had employed Australian ballots." Smith, supra note 2, at 172.

${ }^{37}$ Hall, supra note 25, at 417; Smith, supra note 2, at 173; Walstra, supra note 34, at 111.

${ }^{38}$ EPPERSON, supra note 28, at 84; Note, Constitutionality of Common Provisions in Primary Election Acts, 24 HARV. L. REV. 659, 660 (1911) [hereinafter Constitutionality].

${ }^{39}$ Constitutionality, supra note 38, at 660.
} 
the State undertakes to prepare the ballot and make its use alone mandatory, that official recognition of political groups or parties becomes necessary. In some way now the names which are to appear upon the ballot must be suggested . . .",40

\section{Regulating the Ballot: From 1888 to 1948}

Early state regulation was minimal and aimed to protect voters from the perceived corrupting influences of parties. ${ }^{41}$ State court opinions, therefore, rejected parties' associational arguments against regulation, instead emphasizing voters' rights to "effective, meaningful, and useful ballot[s] and to an orderly and clean electoral process." 42 Early regulation was not burdensome, ranging from a simple request for access to petitions requiring 500 or 1000 signatures. ${ }^{43}$ These light requirements developed from the consensus of the time: ballot access laws were not meant to be substantive barriers, but politics and popularity would determine the number of candidates. ${ }^{44}$ In addition, because of the Constitution's silence, states claimed exclusive power over the ballot ${ }^{45}$ and that the power to create the ballot contained the power to regulate it. $^{46}$

Justice Holmes, while on the Supreme Judicial Court of Massachusetts, deciding whether the Commonwealth's regulations of the Republican caucuses were constitutional, wrote: "The regulations in question provide and govern merely a means by which political parties may get the names of their candidates printed upon the official ballot, and they must govern if they are to provide them." ${ }^{, 47}$ He wrote further that "[t]he Legislature has a right to attach reasonable conditions to that advantage, if it has a right to grant the advantage." 48 In his succinct manner, Justice Holmes illustrated the view that regulations not materially infringing upon voters' rights and designed to promote and

${ }^{40}$ Floyd R. Mechem, Constitutional Limitations on Primary Election Legislation, 3 MiCH. L. REV. 364, 370 (1904).

${ }^{41}$ Smith, supra note 27 , at 172-73.

${ }^{42}$ Winkler, supra note 25 , at $874-75$. Winkler calls this early judicial framework "voters' rights and parties' wrongs." Id. at 898; see EPPERSON, supra note 28, at 86 ("[S]tatutes were voided . . because there was no provision for illiterates or . . . write-in voting.").

${ }^{43}$ Hall, supra note 25, at 417.

${ }^{44}$ Smith, supra note 2, at 173.

45 See Mechem, supra note 40, at 365 ("The right to vote under our political system is not a natural or inherent one, but must be conferred and regulated by the constitutions of the States. Since the federal government has no distinct body of voters of its own, the whole matter must be controlled by the State constitutions, and since it is a general rule of constitutional interpretation that an enumeration of the required qualifications by the constitution is a prohibition upon the requirement of any others, it necessarily follows that whatever the State constitutions provide must usually be both exclusive and conclusive of the whole matter and that the legislature can neither add to nor subtract from the provision so made.").

${ }^{46}$ Constitutionality, supra note 38 , at 659 .

${ }^{47}$ Commonwealth v. Rogers, 63 N.E. 421, 423 (Mass. 1902).

${ }^{48} I d$. 
protect those rights were proper. ${ }^{49}$ Indeed, ballot laws preventing open primaries were struck down in Minnesota, Nebraska, California, and Oregon because they discriminated against smaller parties, involved impermissible regulation of political organizations, and limited voter choice. ${ }^{50}$

Voter choice, however, also justified some regulation. Enhanced voter choice through an expanded ballot had the potential to complicate and lengthen that ballot. To prevent what Chief Justice Paxson of the Supreme Court of Pennsylvania warned would be a ballot "the size of a blanket," the state had the right to regulate, so long as voters' rights were maintained and write-ins were allowed. ${ }^{51}$ Thus, the state enhanced voter choice and efficacy through regulation. ${ }^{52}$ Mechem agreed, suggesting that the constitutional goal was not to have all possible candidates appear on the ballot, but to rely on the write-in space as a constitutional safeguard. ${ }^{53}$ This construction later developed into a ruse for state action aimed at maintaining two-party dominance in response to successful third party candidates.

States reacted to third party threats by making it harder for third party candidates to access the ballot, ${ }^{54}$ and specifically, the Progressive Party's 1948 campaign served as the catalyst for the legal regime George Wallace faced in 1968. Indeed, if Henry Wallace's 1948 campaign had gained more Progressive votes in California or been on the Illinois ballot, he may have sent the election to the House of Representatives. ${ }^{55}$ Also critical was Strom Thurmond's campaign, which unseated President Harry S. Truman as the Democratic nominee in a number of southern states and had the potential to deny Truman and Governor Thomas E. Dewey an Electoral College majority. ${ }^{56}$

A trend toward laws restricting ballot access to third-party candidates is evident in the dwindling number of elected third party and independent representatives in Congress.

${ }^{49}$ See Mechem, supra note 40, at 366; Winkler, supra note 25, at 873-75 ("Between 1886 and 1915, courts by and large rejected the contention that parties were private, voluntary associations entitled to autonomy. Instead, in adjudicating electoral reforms, courts emphasized 'voters' rights' . . . Courts were not merely deferential to state legislatures; some courts invalidated filing fees, candidate oath requirements, and even entire primary schemes. Judicial decisions turned instead on the extent to which reforms were perceived to advance or inhibit the rights of voters, while those of parties were minimized.").

${ }^{50}$ Winkler, supra note 24 , at 888-91.

${ }^{51}$ De Walt v. Bartley, 146 Pa. 529, 543-44 (1892).

${ }^{52}$ Winkler, supra note 25 , at 884.

${ }^{53}$ Mechem, supra note 40, at 372 ("[Limiting the number of candidates on the ballot] does not mean that there might be exclusion from the ballot of the name of any party or candidate, but only that the State would print only certain ones, leaving others to be written in by the voters who so desire."); see Winkler, supra note 25 , at 885 .

${ }^{54}$ Smith, supra note 2, at 174. See also Hall, supra note 25, at 417-18 (stating that only 50,000 signatures were required in 1924 for a new party to be placed on the ballot in all forty-eight states - a mere $0.15 \%$ of those who voted in 1920 , far lower than the 1968 regime).

55 Judith L. Elder, Access to the Ballot by Political Candidates, 83 DiCK. L. REV. 387, 388 (1978).

${ }^{56} I d$. 
From 1896 to 1944,128 third-party Congressmen were elected. ${ }^{57}$ If the Congressional elections from 1888 to 1896 are included, with the understanding that not all states were using the secret ballot, eight Populists entered the 52nd Congress, eleven the 53rd, and nine the 54th. ${ }^{58}$ From 1952 to the present, one Senator ${ }^{59}$ and no Congressmen were elected by a third party. ${ }^{60}$

Independents did no better. Since the 1888 elections, the highest number of independents in the House was three from 1903-05 and two from 2001-03. ${ }^{61}$ In the Senate, from 1888 to present, there have been, at most, two independents at one time; in the 1950s, two switched to the Democratic Party (Senators Thurmond and Morse); and one, Dean Barkley of Minnesota, was appointed to his seat in $2002 .{ }^{62}$ Since 2000, Senator Jeffords switched from the Republican Party and retired, while Senators Lieberman, Sanders, and King won as independents and Murkowski as a write-in, although she identifies as a Republican. ${ }^{63}$ The sparse number of third-party and independent Representatives and Senators illustrates the effectiveness of ballot access laws. ${ }^{64}$

As demonstrated, third-party success was the catalyst of its own political exile from the ballot. ${ }^{65}$ Ohio's ballot access laws followed the same pattern as the national trend, producing the same results. Evolving and tightening at the impetus of third-party threats, Ohio's laws took truly restrictive forms after the 1948 campaign.

\footnotetext{
${ }^{57}$ Smith, supra note 2, at 171.

${ }^{58}$ Id. at 172; Party Divisions of the House of Representatives (1789 to Present), U.S. HOUSE OF REPRESENTATIVES: HISTORY, ART \& ARCHIVES, http://artandhistory.house.gov/ house history/partyDiv.aspx [hereinafter House Division] (last visited Feb. 4, 2013).

${ }^{59}$ The U.S. Senator was James Buckley, elected from the Conservative Party in New York and brother of William F. Buckley. Smith, supra note 2, at 171 n.21.

${ }^{60}$ Id. at 171; see House Division, supra note 58; Party Division in the Senate, 1789-Present, U.S. SENATE: ART \& HISTORY http://www.senate.gov/pagelayout/history/one_item_and_teasers/ partydiv.htm [hereinafter Senate Division] (last visited Feb. 4, 2013).

${ }^{61}$ House Divison, supra note 58 (The numbers include Independent Republican, Independent Populists, and Independent Democrats.).

${ }^{62}$ Senate Division, supra note 60.

${ }^{63} \mathrm{Id}$.

${ }^{64}$ Bradley Smith writes that "the greatest formal obstacle to the emergence of third parties is the U.S. system of single-member plurality districts," arguing that the system "imposes severe penalties on a party hoping to grow over time. . . . [and] creates a powerful incentive . . . to coalesce until just two candidates are left in the running." Smith, supra note 2, at 203-04. This argument is a priori persuasive, but first-pastthe-post does not strangle out third parties. For example, the United Kingdom employs the same constituency-based, plurality system and has a healthy third party currently serving in a coalition government.

${ }^{65}$ Brian L. Porto, The Constitution and the Ballot Box: Supreme Court Jurisprudence and Ballot Access for Independent Candidates, 7 BYU J. PUB. L. 281, 287-88 (1993).
} 


\section{B. Ballot Access in Ohio}

Ohio adopted the Australian ballot in April $1891 .^{66}$ The next year, it enacted its first regulation, requiring signatures equal to one percent by petition or the polling of one percent of the total votes cast in the prior election for ballot access. ${ }^{67}$ The law was upheld and led to a high of seven candidates on the 1908 presidential ballot. ${ }^{68}$

After Vice President Henry Wallace's campaign qualified for the ballot using the independent procedure then in place and the Ohio Court ordered the Secretary of State to place Wallace on the ballot, ${ }^{69}$ Wallace went on to collect $37,000^{70}$ votes, or $1.3 \%{ }^{71}$ of the total popular vote in the state. Given that President Truman beat Governor Dewey by 7000 votes in Ohio in $1948,{ }^{72}$ Wallace's numbers were significant.

Soon thereafter, Ohio moved to preclude third-party candidates from the ballot. ${ }^{73}$ In 1949, it banned independent candidates for President and Vice President from the ballot $;{ }^{74}$ in 1952, it raised the signature requirement from one to seven percent for independent candidates not running for President or Vice President and moved the filing deadline from sixty days before the general election to ninety before the primary. ${ }^{75}$ Having eliminated petition access to the ballot, Ohio then raised the signature requirement for forming a party to fifteen percent of the total votes cast in the last gubernatorial election, ${ }^{76}$ eliminated write-in voting, and imposed a party structure ${ }^{77}$ complete with state and national conventions - to ensure no third party candidate reached the ballot. These changes were bipartisan; a Democratic Governor with both Republicanand Democrat-controlled legislatures enacted the restrictions. ${ }^{78}$

66 Creation of the Board of Elections, THE MAHONING COUNTY COMMUNICATOR, http://www.mahoningcountyoh.gov/DepartmentsAgencies/Departments/BoardofElections/CreationofBOE/t abid/821/Default.aspx (last visited Oct. 22, 2012).

${ }^{67}$ Richard P. Roberts, Note, Ballot Access for Third Party and Independent Candidates After Anderson v. Celebrezze, 3 J.L. \& POL. 127, 138 (1986).

${ }^{68} \mathrm{Id}$.

${ }^{69}$ Brief for Appellants, supra note 12, at 9-10.

${ }^{70}$ Roberts, supra note 67, at 138.

${ }^{71}$ Smith, supra note 2, at 178.

${ }^{72}$ Roberts, supra note 67, at 138-39. Thurmond was not on the Ohio ballot. See GRAF, supra note 7, at 32 .

${ }^{73}$ Brief for Appellants, supra note 12, at 9-10; Roberts, supra note 65, at 139.

${ }^{74}$ Brief for Appellants, supra note 12, at 14.

${ }^{75} \mathrm{Id}$. at $10-11$.

${ }^{76}$ Id. at 16; Roberts, supra note 67, at 139; Smith, supra note 2, at 178.

${ }^{77}$ Smith, supra note 2, at 178.

${ }^{78}$ Political Composition of the Ohio General Assembly - 1900 to 2006, GONGWER NEWS SERVICE, INC., http://www.gongwer-oh.com/public/gahis.html (last visited Oct. 28, 2012); Frank J. Lausche, OHIO HISTORY CENTRAL, http://www.ohiohistorycentral.org/entry.php?rec=1840 (last visited Oct. 28, 2012) (Frank J. Lausche was the Democratic Governor from 1945-47 and again from 1949-57). 
Ohio's plan worked. 1946 was the last year Ohio's gubernatorial election included a third-party candidate on the ballot; ${ }^{79}$ SLP candidate Arla Albaugh received just over 11,000 votes. ${ }^{80}$ In elections following the adoption of the Australian ballot in Ohio, third parties' vote totals - with the noted exceptions of Theodore Roosevelt and his Progressive Party in 1912 and a few Socialists during the time - were not high. ${ }^{81}$ They were, however, cast and tallied and could have proved critical in tight contests. On the other hand, in the fifty-five elections for partisan statewide office since the post-1948 reforms, covering positions from the Governorship to at-large Congressman, Ohio saw no tallied votes for a third-party candidate. ${ }^{82}$ This was the state of Ohio ballot access law when Governor Wallace formed the AIP to gain a spot on the 1968 ballot.

\section{Ohio to the Extreme - An Outlier Making a Bad First Impression ${ }^{83}$}

Ohio's ballot access laws were extreme. As the AIP brief put it, "Ohio's laws are unique insofar as they seem to permit a presidential candidate to gain ballot position by formation of a new political party, but take away that apparent privilege by way of other statutory prohibitions." 84 Comparing Ohio's laws with the other states' restrictions illustrates Ohio's severe burdens.

In 1968, seven states did not permit independent candidates to access the ballot by petition. ${ }^{85}$ However, of those seven, only Ohio imposed significant burdens on party formation. Table 2 below lists those states and their party formation signature requirements. Ohio's requirement, 433,100 signatures, dwarfed the next-highest in Michigan $(30,730)^{86}$ and Florida $(17,845) .{ }^{87}$

${ }^{79}$ Brief for Appellants, supra note 12, at 25.

$80 \quad$ Id. at 30; 1946 General Election Overview, OHIO SECRETARY OF STATE, http://www.sos.state.oh.us/sos/elections/Research/electResultsMain/1940-1949results/46general.aspx (last visited Oct. 28, 2012).

${ }^{81}$ See Brief for Appellants, supra note 12, at 26-31 for vote totals. Theodore Roosevelt outpaced all third-party candidates, receiving 229,807 votes in 1912, while his Progressive Party colleague running for Secretary of State received over 208,000 votes. That same election, President Taft received 278,168; Woodrow Wilson 424,834; Eugene Debs 90,144; the Prohibition candidate 11,511; and the Socialist Labor candidate 2,630 votes. $I d$. at 26 .

82 See Election Results, OHIO SECRETARY OF STATE, http://www.sos.state.oh.us/SOS/elections/ Research/electResultsMain.aspx. See also Brief for Appellants, supra note 12, at 26-31.

${ }^{83}$ The Court addressed four other cases - including the rejection of appeals to place Eugene McCarthy and Black Panther spokesman Eldridge Cleaver on the Californian Presidential ballot for the suits' untimeliness. Fred P. Graham, Using the Court to Get on the Ballot, N.Y. TimeS, Oct. 13, 1968, at E8.

${ }^{84}$ Brief for Appellants, supra note 12, at 32.

${ }^{85}$ Constitutional Law - Elections - Equal Protection [Williams v. Rhodes, 393 U.S. 23 (1968)], 20 CASE W. RES. L. REV. 892, 901 (1968-1969) [hereinafter Elections - Equal Protection].

${ }^{86}$ Michigan required that a new party file a petition six months prior to the election containing a number of signatures equal to at least one percent of the votes cast for Secretary of State in the last election. Brief for Appellants, supra note 11, at 36.

${ }^{87}$ Florida required signatures equal to three-fourths of one percent of registered voters. Brief for Appellants, supra note 12, at 34. 


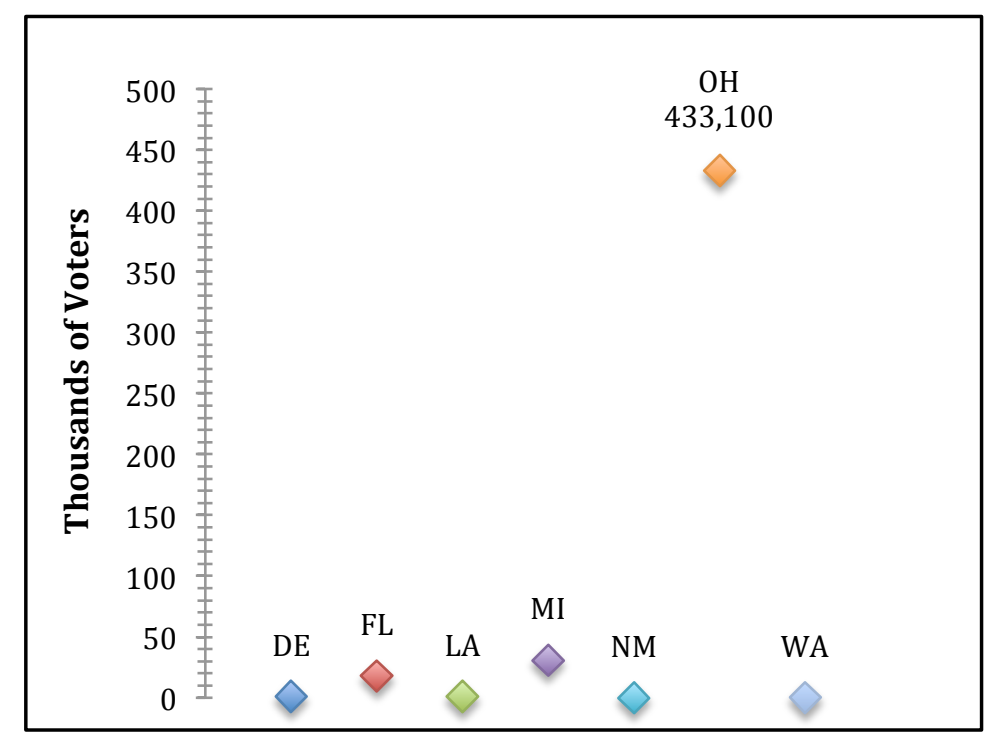

\begin{tabular}{|c|c|}
\hline State & $\begin{array}{c}\text { Required } \\
\text { Membership } \\
\text { Total }\end{array}$ \\
\hline Delaware & 1,050 \\
\hline Florida & 17,845 \\
\hline Louisiana & 1,000 \\
\hline Michigan & 30,730 \\
\hline New Mexico & 0 \\
\hline Ohio & 433,100 \\
\hline Washington & 100 \\
\hline
\end{tabular}

\section{Chart \& Table 2: Party Registration Membership Requirements in 1968 Election $^{88}$}

\footnotetext{
${ }^{88}$ Delaware required parties to represent at least 50 voters in all 21 state senate districts; Louisiana required at least 1000 voters to file their party name and candidates with the Secretary of State; Michigan required petitions with at least one percent of votes cast for the Secretary of State in the last election; New Mexico required only a detailed report be filed; and Washington required a certificate be signed by 100 voters from a nominating convention. Brief for Appellants, supra note 11, at 34, 36, 38, 41; THE COUNCIL of State Governments, The Book of the States 1970-1971 42 (1970); Delaware State Senate, State OF DELAWARE: THE OFFICIAL WEBsite OF THE First http://legis.delaware.gov/LEGISLATURE.NSF/Lookup/SenateHome?open\&nav=senate (last visited Oct. 25, 2012); State of Michigan, General Election Voter Registration/Turnout Statistics, DEPARTMENT OF STATE, http://michigan.gov/sos/0,4670,7-127-1633_8722-29616--,00.html (last visited Oct. 25, 2012).
} 
Ohio required over 400,000 more signatures than each, fourteen and twenty-four times Michigan and Florida's prerequisites, respectively. This enormous gap shows that Ohio was an extraordinary outlier with an onerous party formation regime.

Other states, which allowed independent candidates to obtain ballot position by petition, imposed a minimum signature requirement. Though these requirements were contextually different from Ohio's system, the data indicates that Ohio's fifteen-percent signature requirement to form a party remains among the most extreme, and its real numbers also loom large, as seen in Chart 3. It should be noted that many states base the required number of percentages of vote totals for different offices, from Governor to Secretary of State, while others have absolute number limits. ${ }^{89}$

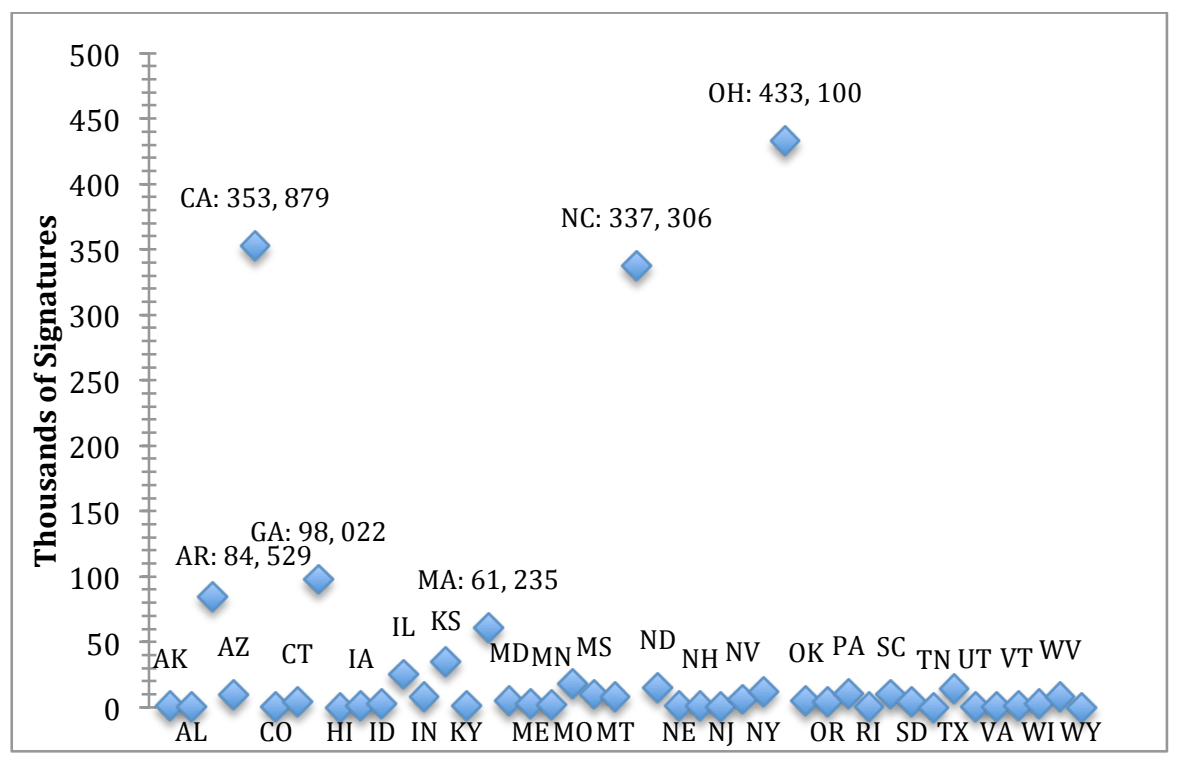

Chart 3: Voter Signatures Required for Ballot Access by Petition ${ }^{90}$

\footnotetext{
${ }^{89}$ See Elections - Equal Protection, supra note 85, at 901 n.30.

${ }^{90}$ The data is collected from a variety of sources and presented in Appendix I. See Brief for Appellants, supra note 12, at 33-42; Benjamin J. Guthrie, Statistics OF THE CONGRESSiOnAl ElECTION OF November 8, 1966 (1967); The Council of State Governments, The Book of the States 1966-1967 27 (1966); The Council of State Governments, The Book of The States 1968-1969 36 (1968); The BOOK OF THE STATES 1970-1971, supra note 88, at 42; Elections - Equal Protection, supra note 85, at 901 n.30; Election of 1964, THE AMERICAN PRESIDENCY PROJECT, http://www.presidency.ucsb.edu/showelection.php?year=1964 (last visited Oct. 23, 2012); GENERAL Election Report of the Secretary of State of the State of Indiana 5 (1966); The Pennsylvania MANUAL 600 (97th ed. 1966). Note that Missouri law called for signatures to number at least one percent of the votes cast in the next general election. Elections - Equal Protection, supra note 85, at 901 n.30. How a candidate could meet that requirement is beyond the author.
} 
The data show that Ohio's laws were among the most burdensome in the nation. The two closest states, California and North Carolina, required at least 80,000 fewer signatures than Ohio, although North Carolina's percentage requirement was high. In addition to these telling numbers, Ohio's signature requirement laws worked in tandem with its provisions banning independent candidates and mandating extremely early deadlines, as well as a required party structure to keep new parties from forming and reaching the ballot.

These comparisons show Ohio's unique position. Ballot access laws developed to protect voters, yet sinister motives altered their rationale and structure as the two-party system sought to maintain its hold. While 1948 represented a national turning point in state legislatures, Ohio went overboard in banning independent candidates and creating a system with stringent requirements as well as interconnected and insurmountable barriers for third parties. Ohio's extreme signature requirements and interwoven laws, what Justice Douglas described as an "entangling web," 91 are critical to understanding Williams. Seeing Ohio's ballot access laws as a nationally unmatched and blatant attempt to freeze out third parties, the Court struck them down in their entirety. ${ }^{92}$ The state's regime practically forced the Court's hand and led to the inevitable conclusion that Ohio's laws must fall. Thus, the Court fashioned a new constitutional jurisprudence in a knee-jerk response to the nation's most complex and extreme example of ballot access laws. How that jurisprudence was fashioned is the subject of Part III.

\section{Drafting Doctrine - The Justices Write}

Existing scholarship on Williams assesses the opinion's jurisprudence but does not account for or examine the internal workings of the Court. Using the papers of Justices Marshall, Black, Douglas, Brennan, and Chief Justice Warren, this Note examines the opinion's evolution and the legal implications of that process. From a potential majority in conference based on the First Amendment to an equal protection opinion written by Justice Black, the Williams decision developed unevenly. This Part analyzes the opinion's development through the Court's internal documents, showing the Court struggling to do justice in a complicated situation.

\footnotetext{
${ }^{91}$ Williams v. Rhodes, 393 U.S. 23, 35 (1968) (Douglas, J., concurring).

${ }^{9}$ See infra Part IV.
} 


\section{A. The Conference}

On October 7, 1968, the Court met in conference the same day that they heard oral argument in Williams. ${ }^{93}$ Justice Douglas' conference notes contain the early impressions of his colleagues. The Chief Justice was concerned with the Court's image, viewing a decision placing Wallace on the Ohio ballot as improper. He thought that the "state action [was] not constitutional," though he "doubt[ed] if [the Court] should give relief," because "if we put him on the ballot we are writing an election statute for the state without giving them a chance to review it." ${ }^{94} \mathrm{He}$ would affirm the decision, not remand, as he wrote in dissent.

For Black, as in his opinion, the case came down to a "denial of equal protection" and a "violation of [the] right to vote and of [the] First Amendment." "95 Harlan said that "[in the absence of a] contrary valid state interest[,] the right of [the] state to choose electors is not an arbitrary power - it must respect other constitutional guaranties - [and that the] party requirements [Ohio imposed were] unconstitutional." 96 The first strand of this argument was wholly adopted in Black's opinion. ${ }^{97}$ Justice Fortas, with whom Marshall agreed, concurred, stating that "the requirement for a new party interferes with $1^{\text {st }}$

${ }^{93}$ See Conference Notes of Justice William O. Douglas (Oct. 7, 1968) (on file in the papers of William O. Douglas, Box 1448). Justice Fortas had two interesting exchanges with the AIP lawyer, David Young, suggesting that the attorney was out of his element. The First:

Justice Abe Fortas: Well, isn't that -- do you really want to rest on the argument that you just elaborated based on Katzenbach against Morgan? $\ldots$

Mr. Young: That is precisely our position if I need plenty other answers suggested that was otherwise then I hope you disregard it, that is precisely our position in this case."

Justice Abe Fortas: Well, we were kind of off [in] leftfield then weren't we?

Mr. Young: Well, --

The Second:

Justice Abe Fortas: You mean you think we have that power and could properly exercise power to direct the Ohio legislature to [place AIP on the ballot]?

Mr. Young: I have no quarrel with that proposition.

Justice Abe Fortas: That's not my proposition, it's yours.

Mr. Young: If it's mine, then I champion it.

WILLIAMS v. RHODES, The Oyez Project at IIT Chicago-Kent College of Law, http://www.oyez.org/cases/1960-1969/1968/1968_543 (last visited February 6, 2013).

${ }^{94}$ Conference Notes of Justice William O. Douglas (Oct. 7, 1968) (on file in the papers of William O. Douglas, Box 1448).

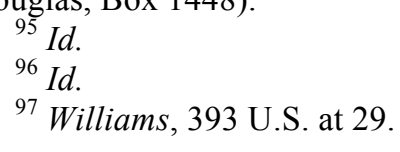


Amendment rights." 98 Justice Brennan agreed, saying it's a "First Amendment problem" with an "unreasonable burden on that right," and that "all restrictions in [the Ohio] Act put an impermissible burden on [the] First Amendment." 99

Justice Stewart's initial thoughts are most interesting, as his position changed between conference and the opinion's announcement. In the opinion, he agreed with the denial of relief for the SLP but dissented from the AIP's result. ${ }^{100}$ In conference, however, Douglas wrote that Stewart "gives relief to Wallace," but also noted that "Ohio can do what it did here [because] electors can't be controlled by race or religion - but the control is very wide." ${ }^{101}$ For Justice White, the question was simple: "a state may restrict [the] choice to two candidates." 102

The notes show that although the Justices approached the case differently, they largely agreed that the First Amendment was most applicable to the case, with only Black discussing the Equal Protection Clause. This focus may explain Douglas' subsequent actions emphasizing the First Amendment rationale, given that Black assigned the opinion to himself and focused on the Equal Protection Clause. In fact, fifteen years later the Court switched and embraced the First Amendment as a reservoir for ballot access rights.

\section{B. The Douglas "Memo"}

Douglas was known for the speed of his pen. On October 8 - the day after oral argument and conference - he circulated an opinion. The accompanying memorandum stated: "I have taken the liberty of circulating this rough draft opinion with the thought that it might possibly be helpful in expediting our disposition of the cases." ${ }^{103}$ Douglas re-circulated this "draft opinion" on October ninth, twice on October tenth, and four times on October eleventh, ${ }^{104}$ despite the fact that Black had the assignment. ${ }^{105}$

Douglas' motive may have been to persuade his colleagues of his views. But his conference notes and use of concluding language suggest he hoped to co-opt the opinion. Indeed, he concluded each draft as if he were speaking for the Court, only replacing the

${ }^{98}$ Conference Notes of Justice William O. Douglas, supra note 93.

${ }^{99}$ Id.

${ }^{100}$ Williams, 393 U.S. at 61 (Stewart, J., dissenting).

${ }^{101}$ Conference Notes of Justice William O. Douglas, supra note 93.

${ }^{102} I d$.

${ }^{103}$ Memorandum from Justice William O. Douglas to the Supreme Court (Oct. 8, 1968) (on file in the papers of William O. Douglas, Box 1448).

${ }^{104}$ See generally the papers of William O. Douglas. Figures are derived from tallying the circulated drafts that appear in these papers.

${ }^{105}$ Chief Justice Earl Warren, Tally Sheet on Associate Justices' Opinions (Oct. 15, 1968) (on file in the papers of Earl Warren, Box 569). The Tally Sheet describes Justice Douglas' opinion as a "Memo." Id. 
plural "we" with the singular "I" on October $10 .{ }^{106}$ However, as if clinging to hope, he left the conclusion "It is so ordered." ${ }^{107}$ Finally, on the eleventh, he replaced the order with, "Hence I concur in part and dissent in part from the Court's opinion," 108 before eliminating this partial dissent and concluding with, "Hence I concur in today's decision," ${ }^{109}$ in his final draft. This evidence suggests Douglas had an eye on writing the Court's opinion.

A note he wrote to his clerk further supports this interpretation. In his handwritten note, Douglas wrote: "I have circulated the Ohio opinion with the view that it may be useful in drafting (by someone) of an opinion to come down this week. So, check it over carefully as if I were filing the opinion."110

Given that his conference notes indicate that Justices Harlan, Brennan, Fortas, and Marshall agreed with his emphasis of the First Amendment over the Equal Protection Clause, ${ }^{111}$ Douglas' pursuit of the opinion makes sense. His colleagues' agreement provides motive and Douglas' opinion drafts and his handwritten memo instill intent in his actions. Yet, no other justice joined him, leaving the unanswerable question, why?

\section{Black's Opinion \& Its Development}

Justice Black first circulated his opinion, his third draft, on October 9, the day after Douglas. ${ }^{112}$ He would go on to write four more drafts for circulation, making changes at the behest of his colleagues - Justices Fortas and Brennan offered memoranda urging

${ }^{106}$ Memorandum from Justice William O. Douglas to the Supreme Court (Oct. 10, 1968) (on file in the papers of William O. Douglas, Box 1448) ("I agree we should affirm the District Court in rejecting the claim of the Socialist Labor Party and modify its judgment respecting the Wallace American Independent Party by directing that that party be place on the ballot."). Justice Douglas attached this rider on October 10, 1968. Id.

${ }^{107}$ Id.

${ }^{108}$ Memorandum from Justice William O. Douglas to the Supreme Court (Oct. 11, 1968) (on file in the papers of William O. Douglas, Box 1448).

${ }^{109}$ See Williams v. Rhodes, 393 U.S. 23, 41 (1968) (Douglas, J., concurring).

${ }^{110}$ Memorandum from Justice William O. Douglas to Peter K. Westen, law clerk, (Oct. 1968) (on file in the papers of William O. Douglas, Box 1448).

${ }^{111}$ Justice Douglas does note: "The Equal Protection Clause of the Fourteenth Amendment permits the States to make classifications and does not require them to treat different groups uniformly. Nevertheless, it bans any 'invidious discrimination.' // That command protects voting rights and political groups as well as economic units, racial communities, and other entities." His focus, though, is on the First Amendment, as he continues: "Cumbersome election machinery can effectively suffocate the right of association, the promotion of political ideas and programs of political action, and the right to vote. The totality of Ohio's requirements has those effects. It is unnecessary to decide whether Ohio has an interest, 'compelling' or not, in abridging those rights, because 'the men who drafted our Bill of Rights did all the 'balancing' that was to be done in this field." Williams, 393 U.S. at 39-40 (Douglas, J., concurring) (internal citations omitted).

112 Justice Hugo L. Black, Draft Opinion of Williams v. Rhodes (Oct. 9, 1968) (on file in the papers of Hugo L. Black, Box 411). 
changes, having conferred in their suggestions ${ }^{113}$ - and in response to Justice Stewart's

dissent, some of which had significant implications and effects on the Court's jurisprudence.

Justice Fortas asked for five changes, one of which is particularly important. He wrote:

It is my understanding that the Socialist Party was entitled to relief (except that time bars full relief) because the unconstitutionality of Ohio's requirements leaves Ohio with no restrictions on qualification of a party. Unless this is made clear, perhaps the opinion would lead some to think that we believe that the Constitution requires a ballot place to a party with only 108 members. ${ }^{114}$

Justice Fortas was prescient; Black did not make this change, and the case would lead to bizarre results within two years in New York. ${ }^{115}$

Justice Brennan offered five concrete changes, all of which were made, most focusing on the SLP's size and Black's characterizations of the party, and included a stronger conclusion with regards to the Court's refusal to grant the SLP relief. ${ }^{116}$ Justice Marshall concurred, writing, "I agree with the suggestions made by Justices Brennan and Fortas, and urge you to accept them."

Justice Brennan also seems to have spoken with Justice Black and influenced the opinion's fourth part. Justices Black and Brennan wrote a two-page section, which did not make the final opinion but which sharply distinguishes between the AIP and SLP, on October 9 at five in the evening. ${ }^{118}$ This timing is important because Justice Black first circulated his draft opinion at nine that night, without this section. This section may have had profound effects on Williams' progeny and ballot access law. It read:

As we have said, we have held the State's restrictive election law, as a whole, to violate the Equal Protection Clause. The circumstances under

\footnotetext{
${ }^{113}$ Memorandum from Justice William J. Brennan, Jr. to Justice Hugo L. Black (Oct. 10, 1968) (on file in the papers of Hugo L. Black, Box 411).

${ }^{114}$ Memorandum from Justice Abe Fortas to Justice Hugo L. Black (Oct. 10, 1968) (on file in the papers of Hugo L. Black, Box 411). Justice Fortas also suggested a reference to the Due Process Clause was acceptable, but concluded, "I guess I understand the difference between your view and that of Brother Harlan - and I prefer to stay out of range." Id.

115 See infra Part V.

${ }^{116}$ Compare Memorandum from Justice Brennan, supra note 113, with Williams, 393 U.S. at 35. Indeed, the opinion's language, from "Certainly at this late . . . for this election," is Brennan's. Williams, 395 U.S. at 35.

${ }^{117}$ Memorandum from Justice Thurgood Marshall to Justice Hugo L. Black (Oct. 10, 1968) (on file in the papers of William O. Douglas Box 1448).

${ }_{118}$ Justice Hugo L. Black, Draft Opinion of Williams v. Rhodes, supra note 112, at 10-11 (page 10 notes in the top left corner: "Redictated @ J. Brennan's visit 10/9/68 HLB:WJB:FL 5 PM").
} 
which we have held that, however, are different in the two cases. The Socialist Labor Party is an old party which has been on the ballot of many States for many years. It was formerly allowed to have its name on the ballot in the State of Ohio but the laws have now changed that. On the contrary, the Ohio Independent Party is a wholly new party, and has been in the daily process for several years trying to establish itself in the various States. It seems to have begun to try to establish itself in Ohio in January 1968. The Ohio restrictive laws required it to file certain papers in February which this newly-developed party found impossible to do. It did, however, in 1968, obtain almost a half million signers to the petition it filed with the State asking that it be given a place on the ballot. We cannot treat as identical, for purposes of state election law, a 28-year old party which has only 108 members and a party in its first year which already has a membership in the hundreds of thousands. Under these circumstances we think that the State can give no compelling reason for barring from its ballots this new Independent Party on the grounds it did, including the fact that it had filed its papers too late. ${ }^{119}$

This language demonstrates that the justices saw the cases as jurisprudentially distinct and did not deny the SLP access simply because of the impossibility of such an act. Rather, it suggests that the Court thought the AIP's size was critical to its ballot access, and would not have granted the SLP a place on the ballot had it, in fact, applied for such relief earlier. Omitting this language had important consequences, as Justice Fortas warned of in his letter, merely three years later in Rockefeller v. Socialist Workers Party and Jenness v. Fortson. ${ }^{120}$

The other significant change made in the opinion relates to the specifics of Ohio's ballot access law. In early drafts, Justice Black wrote that Ohio's goal of a majority victor in an election could be achieved in other ways, namely a run-off election. ${ }^{121}$ Justice Stewart's draft attack on this suggestion was excoriating, and Black removed it altogether. Stewart had argued that the state cannot be compelled to use a run-off system, and that such a system would result in state run-off elections being held after the national election. ${ }^{122}$ Ironically for Black and the Court, Stewart substituted this language with his

\footnotetext{
${ }^{119} I d$.

${ }^{120}$ See infra Part V; Jenness v. Fortson, 403 U.S. 431 (1971); Rockefeller v. Socialist Workers Party, 400 U.S. 806 (1970).

${ }^{121}$ Justice Hugo L. Black, Draft Opinion of Williams v. Rhodes, (Oct. 10, 1968), at 9 ("But since this legitimate interest could be served by many other procedures, such as a run-off election, which would not abridge the rights involved here, the State's asserted interest provides no basis for upholding this very severe restriction on voting and associational rights.").

${ }^{122}$ Justice Potter Stewart, First Draft Concurrence of Williams v. Rhodes 9-11 (Oct. 12, 1968) (on file in the papers of Hugo L. Black, Box 411).
} 
much stronger constitutional argument that state control over the selection of electors is nearly plenary. ${ }^{123}$

These internal documents illustrate Justice Black's opinion's many loose ends and lack of foresight. His opinion left open the question of how courts should interpret the SLP's and similar claims, which led to new struggles based on the implications of the Williams opinion and the high barriers strict scrutiny placed on states. They also reveal tension between Justice Douglas' concurrence and Justice Black's opinion. This tension began at conference, where it seems a majority supported a straightforward First Amendment rationale. Indeed, Douglas' First Amendment principles did not require a strict scrutiny test, while Black's did. However, Black, as Senior Associate Justice, assigned the opinion to himself, won a majority, and struck down the law under the Equal Protection Clause. This early split plagues the doctrine even today.

\section{THE DeCISION}

The prior sections explained how the Court arrived at its decision. A combination of George Wallace's popularity and strength, the extremeness of Ohio's laws vis-à-vis the rest of the nation, and Justice Black's decision to assign the opinion to himself produced Williams v. Rhodes. The popular Governor Wallace faced an injustice in Ohio, which the Court remedied, but in doing so, it plunged ballot access law into a doctrinal morass. This part examines the various opinions in detail.

\section{A. Black's Majority Opinion}

Justice Black published the Court's opinion on October 15, 1968, the last day Ohio could comply with a decision in time for the election. ${ }^{124}$ Black held that Ohio's legal regime violated voters' equal protection rights. Joined by Justices Fortas, Brennan, and Marshall, and with concurrences from Justices Douglas and Harlan, the result - placing the AIP on the ballot but keeping the SLP off - garnered six votes, while the rationale carried four. ${ }^{125}$

Black rejected Ohio's claims that the case presented a non-justiciable political question and that it enjoyed plenary power under Article II, Section 1 of the Constitution. ${ }^{126}$ Black brushed aside Ohio's first claim, citing Baker v. Carr. ${ }^{127}$ He wrote,

${ }^{123}$ See infra Part IV; Williams v. Rhodes, 393 U.S. 23, 48 (1968) (Stewart, J., dissenting).

${ }^{124}$ Fred P. Graham, Supreme Court Bars McCarthy and Cleaver From Coast Ballot, N.Y. Times, Oct. 7,1968 , at 34 .

${ }^{125}$ Williams, 393 U.S. at 23.

${ }^{126} I d$. at 28-29; U.S. CONST. art. II, § 1, cl. 2 ("Each State shall appoint, in such Manner as the Legislature thereof may direct, a Number of Electors, equal to the whole Number of Senators and Representatives to which the State may be entitled in the Congress: but no Senator or Representative, or Person holding an Office of Trust or Profit under the United States, shall be appointed an Elector.”). 
"Ohio's claim . . . requires very little discussion. . . . These cases do raise a justiciable controversy under the Constitution and cannot be relegated to the political arena." ${ }^{128} \mathrm{He}$ then held Ohio's Article II powers "may not be exercised in a way that violates other specific provisions of the Constitution," specifically the Fourteenth Amendment's Equal Protection Clause. ${ }^{129}$ Black believed the Clause barred state discriminatory practices that infringed Bill of Rights' freedoms, and he seems to have found the right to vote in the Constitution's design. ${ }^{130}$

Employing the roots of a traditional equal protection inquiry, Black held that Ohio ballot access law burdened both the right of political association and the right to cast a vote effectively. ${ }^{131}$ He wrote:

No extended discussion is required to establish that the Ohio laws before us ... place substantially unequal burdens on both the right to vote and the right to associate. The right to form a party for the advancement of political goals means little if a party can be kept off the election ballot and thus denied an equal opportunity to win votes. So also, the right to vote is heavily burdened if that vote may be cast only for one of two parties at a time when other parties are clamoring for a place on the ballot. ${ }^{132}$

Furthermore, because the rights burdened were First Amendment freedoms, Ohio needed a compelling state interest to justify these substantial burdens. ${ }^{133}$

Justice Black found none, rejecting Ohio's argument that the ballot access laws encouraged compromise and political stability, promoted a majority winner, enhanced voter choice on leadership and issues by requiring party formation, and prevented voter confusion by limiting ballot size. ${ }^{134}$ Black rejected each claim with specificity ${ }^{135}$ before concluding, "[b]ut here the totality of the Ohio restrictive laws taken as a whole imposes a burden on voting and associational rights which we hold is an invidious discrimination,

${ }^{127}$ Williams, 393 U.S. at 28 (citing Baker v. Carr, 369 U.S. 186, 208-237 (1962)).

${ }^{128}$ Id. at 28

${ }^{129} \mathrm{Id}$. at 29.

${ }^{130}$ G. EdWARd White, The AMERICAN Judicial Tradition: Profiles of LeAding American JudGeS 306 (3d ed. 2006).

131 Williams, 393 U.S. at 30.

${ }^{132}$ Id. at 31 .

${ }^{133}$ Id. (citing NAACP v. Button, 371 U.S. 415 (1963) for the application of strict scrutiny). However, Button was not decided on equal protection grounds. 371 U.S. at 444 ("Because our disposition is rested on the First Amendment as absorbed in the Fourteenth, we do not reach the considerations of race or racial discrimination which are the predicate of petitioner's challenge to the statute under the Equal Protection Clause.").

${ }^{134}$ Williams, 393 U.S. at 31-33.

135 Ohio's system, according to Justice Black, created an improper monopoly for the Democratic and Republican parties, stifled political growth of other parties, prevented a new party from ever attaining the ballot, and was not necessary to prevent unwieldy ballots. Id. at 32-34. 
in violation of the Equal Protection Clause." ${ }^{\prime 136}$ Finally, Black ordered the AIP remain on the ballot but denied the SLP ballot placement, noting that the delay was too great for Ohio to print another set of ballots so close to the election. ${ }^{137}$ The decision to apply strict scrutiny and strike the totality of Ohio's laws had profound effects on later jurisprudence. $^{138}$

\section{B. The Douglas Concurrence}

Justice Douglas' concurrence focused on the First Amendment. He emphasized that Ohio precluded third parties from the presidential ballot by spinning "an entangling web of election laws." 139 The web was composed of early timeframes and required elaborate party machinery and structure with state and national conventions. ${ }^{140} \mathrm{He}$ wrote, "These barriers of party, timing, and structure are great obstacles. Taken together they render it difficult, if not impossible, for a man who disagrees with the two major parties to run for President in Ohio, to organize an opposition, and to vote a third ticket."141

Write-ins were no relief either. A vote for President is only efficacious if it corresponds to a slate of electors, and because Ohio restricted slates to major parties, write-ins were a waste. ${ }^{142}$ The Article II question for Douglas was whether Ohio, having provided for popular election, could "encumber that right" with the challenged conditions; ${ }^{143}$ it could not.

Douglas eschewed the Equal Protection Clause. For him, the right to vote stood at the root of the protected First Amendment rights of expression and assembly, ${ }^{144}$ and, having been made applicable through the Fourteenth Amendment to the states, was beyond Ohio's reach. ${ }^{145}$ An equal protection analysis, therefore, was unnecessary:

Cumbersome election machinery can effectively suffocate the right of association, the promotion of political ideas and programs of political action, and the right to vote. The totality of Ohio's requirements has those

\footnotetext{
${ }^{136}$ Id. at 34 .

${ }^{137}$ Id. at $34-35$.

${ }^{138}$ See infra Part VI.

${ }^{139}$ Williams, 393 U.S. at 35-36 (Douglas, J., concurring).

${ }^{140} \mathrm{Id}$. at 36-37.

${ }^{141} I d$. at 38 .

${ }^{142} I d$. at 37. Eight parties had slates of electors registered with the Ohio Secretary of State. 1960-1969 Official Election Results: Presidential Electors, THE OHIO SECRETARY OF STATE, http://www.sos.state.oh.us/sos/elections/Research/electResults Main/1960-1969Results/68electors.aspx (last visited Oct. 25, 2012). This was likely a result of the Williams decision. If not, it undermines Douglas' claim.

${ }^{143}$ Williams, 393 U.S. at 38 (Douglas, J., concurring).

${ }^{144} \mathrm{Id}$. at 38-39.

${ }^{145} \mathrm{Id}$. at 38-40.
} 
effects. It is unnecessary to decide whether Ohio has an interest, 'compelling' or not, in abridging those rights, because 'the men who drafted our Bill of Rights did all the 'balancing' that was to be done in this field. ${ }^{146}$

Reaching a step beyond the Court, Douglas would have granted the SLP declaratory relief, believing its claim was as strong as the AIP's, but also finding that it brought that claim too late for the election. ${ }^{147}$

\section{Justice Harlan's Concurrence}

Justice Harlan preferred to rest the decision on due process grounds, concluding that "Ohio's statutory scheme violates the basic right of political association assured by the First Amendment which is protected against state infringement under the Due Process Clause of the Fourteenth Amendment." 148 For Harlan, the Electoral College's raison d'être - "to permit the most knowledgeable members of the community to choose the executive" 149 - was subsumed by Ohio's laws, which effectively declared "that an entire class of citizens is ineligible for the position of Elector, and that class is defined in a way in which individual merit plays no part . . ." "150 From this historical reading, Justice Harlan determined that the Electoral College's original understanding was not threatened by the Court's ruling that states do not enjoy the power for arbitrary action under Article II without an overriding state interest. ${ }^{151}$ Finally, Harlan pointed out that Ohio's fifteen percent signature requirement would enable at most eight candidates to make the ballot, the two major parties and six others, a number that historically did not cause voter confusion. ${ }^{152} \mathrm{He}$ concluded: "In sum, I think that Ohio has fallen far short of showing the compelling state interest necessary to overcome this otherwise protected right of political association." 153

\section{The Dissents: Justices Stewart and White and Chief Justice Warren}

Justice Stewart, though concurring in the Court's denial of relief to the SLP, dissented in its ruling with regard to the AIP. ${ }^{154} \mathrm{He}$ first concluded that Article II granted the state near plenary powers in the appointment of electors, and that the Equal Protection Clause

${ }^{146} \mathrm{Id}$. at $39-40$.

${ }^{147} \mathrm{Id}$. at $40-41$.

${ }^{148} \mathrm{Id}$. at 41 (Harlan, J., concurring).

${ }^{149}$ Id. at 43.

${ }^{150} \mathrm{Id}$. at 44 .

${ }^{151}$ Id. at 45.

${ }^{152} \mathrm{Id}$. at 46-47. This numerical limit only applies if an individual can sign no more than one petition.

${ }^{153}$ Id. at 47; Justice Harlan's concurrence also illustrates that incorporation of the First Amendment takes place through substantive due process and produces more flexible doctrines than the First Amendment proper in its application to the federal government.

${ }^{154}$ Id. at 35 (Stewart, J., concurring); id. at 48-61 (Stewart, J., dissenting). 
did not circumscribe that power. ${ }^{155}$ Rather the Fifteenth, Nineteenth, and TwentyFourth Amendments were the only substantive limits on the states' power. ${ }^{156}$ However, he then conceded that the Equal Protection Clause would prohibit the state from discriminating against electors on religious or political grounds, ${ }^{157}$ but having found no such discrimination, he declared the state interest in creating majority victors sufficient for the Ohio scheme. ${ }^{158}$ Next, Justice Stewart found ballot access denial did not infringe upon the freedom of association, since citizens were still permitted to form political parties. ${ }^{159}$ Finally, he advocated a less stringent level of scrutiny, akin to rational basis review. ${ }^{160}$

Like Justice Stewart, Justice White concurred in the Court's denial of relief to the SLP but dissented from its outcome and rationale in the AIP's case. ${ }^{161}$ Justice White's opinion is brief and his rationale straightforward. For him, neither the Equal Protection Clause nor the Due Process Clause prevented Ohio from requiring that electors be selected through a party process. ${ }^{162}$ Additionally, the AIP's late start on signature collection demonstrated that the party made no attempt to comply with Ohio's laws, meaning it was entitled to no relief. ${ }^{163}$ Furthermore, for the Justice, the Court's combination of Ohio's other provisions with the fifteen percent signature requirement in its comprehension of the problem was inappropriate. ${ }^{164}$

Chief Justice Warren's dissent stressed the truncated timeline of the decision, noting that the Court had seven days to decide this case when it took a year to decide Baker $v$. Carr. ${ }^{165}$ Because this case's ramifications were great, Warren would have remanded for "clearer determination of the serious constitutional questions raised . . .."166 The Chief did not agree with the Court's procedural posture or Justice Stewart's equal protection analysis and pointed out that there was no way to verify the collected signatures, as Ohio had not made those determinations. ${ }^{167} \mathrm{He}$ also found that Article II's express grant of power distinguished the case from contexts in which the court was concerned with preserving the state's powers, such as apportionment and school desegregation, that

${ }^{155}$ Id. at 49-50 (Stewart, J., dissenting).

${ }^{156} I d$. at 50. Presumably the Twenty-Sixth Amendment would join this list.

${ }^{157}$ Id. at 50-51.

${ }^{158}$ Id. at 53-54.

${ }^{159}$ Id. at 60.

${ }^{160} \mathrm{Id}$. at 51 .

${ }^{161} \mathrm{Id}$. at 61 (White, J., concurring and dissenting).

${ }^{162} \mathrm{Id}$. at 61-62.

${ }^{163} \mathrm{Id}$. at $62-63$.

${ }^{164}$ Id. at 63.

${ }^{165}$ Id. (Warren, C.J., dissenting)

${ }^{166} \mathrm{Id}$. at 63,70 .

${ }^{167} \mathrm{Id}$. at 64-66. 
neither party was entitled to relief, and that each should be treated the same based on constitutional principles. ${ }^{168}$ It was an unheeded word of caution from the outgoing Chief.

The Court faced a novel legal question in Williams, resulting in the varying conclusions and rationales employed by the Justices. The ensuing disparity shows how the Court struggled with Ohio's restrictive ballot access laws in a field that touches upon many linked constitutional doctrines. The right to vote and the concomitant right to the ballot are necessary in our representative democracy, but their constitutional basis was unclear until Williams. Nevertheless, Black's opinion left a confusing marker for future cases. In voiding the totality of Ohio's ballot access laws, the Court left no guidance as to what regulations were permitted. This omission, as early editorials and legal articles predicted, ${ }^{169}$ had and continues to have profound impacts on future decisions, as demonstrated in Part V.

\section{WRESTLING WITH WILLIAMS: \\ THE COURT'S SUbSEQUENT SEARCH FOR A STANDARD}

Williams has suffered much criticism in legal academia. Scholars view the opinion as a false start or an unfulfilled promise, attacking it for its broad implications and vague guidance. They characterized the Court's opinion and the jurisprudence it spawned as a "thorny . . . political thicket,"170 "flawed from [its] inception,",171 "positively delphic,",172 and "erratic." 173 Professor Todd Zywicki described the variable doctrine as a "lurch[] from one standard to another, consistent only in its inability to maintain consistency."174 A more charitable student note found that the Court was consistent in its rejection of a mathematical formula, but that its "approach to constitutional scrutiny of state [ballot] regulations is unsettled." ${ }^{175}$ Criticism of the case emanates from across the legal spectrum, with Professor Zywicki favoring a return of ballot access regulation to the

${ }^{168} I d$. at $64,68$.

${ }^{169}$ See John Barton, The General Election Ballot: More Nominees or More Representative Nominees, 22 STAN. L. REV. 165, 173 (1970) (arguing Williams was unclear in its equal protection application); Note, II. Access to the General Election Ballot for Political Parties and Independent Candidates, 88 HARV. L. REV. 1121, 1134 (1975) (finding the description of the content of a right to vote effectively was cryptic); Editorial, A Win for Wallace, EvENING STAR, Oct. 19, 1968, at A4 ("[I]t must be conceded that the court's majority opinion gives precious little guidance as to what Ohio may be permitted to do in the future. . . Ohio apparently will have to revise its laws . . . and hope that its new standards will not run afoul of any judicial prohibition.”).

${ }^{170}$ Darla Shaffer, Survey, Tenth Circuit Survey: Ballot Access Laws, 73 DENV. U. L. REV. 657,660 (1996).

${ }^{171}$ Zywicki, supra note 24, at 126.

${ }^{172}$ Id. at 117 (quoting LAUREnCE Tribe, American CONSTITUtional LAw $\S \S 13-201106$ (2d ed. 1988)).

${ }^{173}$ Smith, supra note 2, at 187.

${ }^{174}$ Zywicki, supra note 24, at 108.

${ }^{175}$ Francine Miller, Note, Fairness in the Election Arena: Congressional Regulation of Federal Ballot Access, 32 N.Y.L. SCH. L. REV. 903, 921 (1987). 
states, ${ }^{176}$ and Professor Bradley Smith calling for strict scrutiny analysis for all ballot restrictions. ${ }^{177}$ This criticism analyzes the jurisprudential evolution post-Williams where the Court switched scrutiny and specificity levels without overruling itself. ${ }^{178}$

Most narratives of the Court's struggle with Williams are constructed around three cases. Williams is a first effort; Jenness v. Fortson ${ }^{179}$ becomes the Court's answer to the implications of Williams; ${ }^{180}$ and the 1983 balancing test developed in Anderson $v$. Celebrezze ${ }^{181}$ abandons the old judicial framework while accommodating the cases in between. Authors trace this evolution from Williams to today, citing intervening cases, such as Rockefeller v. Socialist Workers Party, ${ }^{182}$ Storer v. Brown, ${ }^{183}$ and American Party of Texas $v$. White ${ }^{184}$ as illustrative of a shift towards greater deference to the states. ${ }^{185}$ Today, the Anderson test, as encapsulated in Burdick v. Takushi, ${ }^{186}$ serves as one standard, while the Williams strain endures, most recently in Norman v. Reed. ${ }^{187}$ This section describes the Court's public and private struggle with Williams' implications, augmenting the traditional jurisprudential analysis with historical evidence taken from the Justices' papers. A picture of a Court struggling with scrutiny levels, doctrinal underpinnings, and permissible state interests emerges. The section concludes with a contemporary application of ballot access jurisprudence in Perry v. Judd, ${ }^{188}$ demonstrating Williams and its progeny's lingering ill effects before proposing a solution.

${ }^{176}$ Zywicki, supra note 24, at 133.

${ }^{177}$ Smith, supra note 2, at 168.

${ }^{178}$ See Benjamin D. Black, Note, Developments in the State Regulation of Major and Minor Political Parties, 82 CoRnell L. ReV. 109, 123 (1996); Amber Juffer, Note, Living in a Party World: Respecting the Role of Third Party and Independent Candidates in the Equal Protection Analysis of Ballot Access Cases, 56 DRAKE L. REV 217, 221 (2007); Roberts, supra note 67, at 128.

${ }^{179}$ Jenness v. Fortson, 403 U.S. 431 (1971).

${ }^{180}$ See Zywicki, supra note 24, at 136.

${ }^{181}$ Anderson v. Celebrezze, 460 U.S. 780 (1983).

${ }^{182}$ Rockefeller v. Socialist Workers Party, 314 F. Supp. 984 (S.D.N.Y.), aff'd mem., 400 U.S. 806 (1970). See Smith, supra note 2, at 186; Zywicki, supra note 24, at 88.

${ }^{183}$ Storer v. Brown, 415 U.S. 724 (1974). See Hall supra note 25, at 431-33; Miller, supra note 175, at 913-16; Zywicki, supra note 24, at 114.

${ }^{184}$ American Party of Texas v. White, 415 U.S. 767 (1974). See Miller, supra note 175, at 916; Smith, supra note 2, at 187; Zywicki, supra note 24, at 114.

${ }^{185}$ Smith, supra note 2, at 181 ("The language of Williams $v$. Rhodes was sufficiently broad to raise doubts as to whether any state's ballot-access law could pass constitutional muster. Judging from the ballotaccess decisions that followed Williams, however, the Court may have gone further than it intended. The history of ballot-access adjudication in the past twenty years is one of retreat from the broad implications of Williams."').

${ }^{186}$ Burdick v. Takushi, 504 U.S. 428 (1992).

${ }^{187}$ Norman v. Reed, 502 U.S. 279 (1992).

${ }^{188}$ Perry v. Judd, 840 F. Supp. 2d 945 (E.D. Va. 2012). 


\section{A. The Struggle Begins: What Scrutiny? The Jenness Jurisprudence - 1971-1983}

Three years after dissenting in Williams, Justice Stewart wrote the Court's opinion in Jenness v. Fortson in 1971. He found that the Georgia provisions, without examining them in their totality, did not violate voter equal protection. ${ }^{189}$ Stewart stressed the factual differences between Williams and Jenness, concluding that Georgia did not invidiously discriminate "in recognizing [the] differences [between political parties and organizations] and providing different routes to the printed ballot. Sometimes the grossest discrimination can lie in treating things that are different as though they were exactly alike . . . ." 190 The opinion never used the word "compelling" and found only "an important state interest in requiring some preliminary showing of a significant modicum of support before printing the name of a political organization's candidate on the ballot . . " ${ }^{\prime 191}$ The Court, therefore, applied a standard that seems closer to intermediate or rational basis than strict scrutiny and unconcerned with the totality of the statutory scheme.

Professor Zywicki, building on Professor Smith's article, argued convincingly that a lower court case in the interim, Rockefeller v. Socialist Workers Party, ${ }^{192}$ focused the Court on the real-world implications of Williams and influenced Jenness. ${ }^{193}$ Rockefeller, summarily affirmed, declared New York's geographical distribution requirement for petition signatures unconstitutional. ${ }^{194}$ In response, three candidates formed sham parties and the ballot went from seven to ten nominees. ${ }^{195}$ With room for only nine, a crisis developed until the Conservation Party was dropped because of its name's similarity with the Conservative Party. ${ }^{196}$ According to Zywicki and Smith, the Court heard Jenness with Rockefeller on its mind and adjusted its posture accordingly. ${ }^{197}$

${ }^{189}$ Justice Black, who died three months later, concurred without opinion. Jenness v. Fortson, 403 U.S. 431, 442 (1971). The provisions separated political parties from political bodies and, reserving a place on the ballot for the former, required the latter to obtain signatures from "not less than five percent of the total number of electors eligible to vote in the last election for the filling of the office the candidate is seeking;" the provisions also imposed the same deadline as the candidate filing deadline for party primaries and enabled write-ins. $I d$. at 433-34.

${ }^{190}$ Id. at 441-42.

${ }^{191}$ Id. at 442.

192 Rockefeller v. Socialist Workers Party, 314 F. Supp. 984 (S.D.N.Y. 1970), aff'd, 400 U.S. 806 (1970).

${ }^{193}$ Smith, supra note 2, at 186; Zywicki, supra note 24, at 113.

${ }^{194}$ Rockefeller v. Socialist Workers Party, 314 F. Supp. 984 (S.D.N.Y. 1970), aff'd, 400 U.S. 806 (1970).

195 Smith, supra note 2, at 186.

${ }^{196}$ Id. New York, unlike many states, protects fusion nominations, where a candidate can appear on the ballot under multiple party lines, as a state constitutional right. See Matter of Hopper v. Britt, 203 N.Y. 144 (1911).

${ }^{197}$ Smith, supra note 2, at 185-86; Zywicki, supra note 24, at 113 . Internal documents neither prove nor disprove this assertion. Justice Blackmun provides some hand-written notes of four justices' thinking. Marshall noted that " $5 \%$ [is] too much in Ga." Notes of Justice Harry A. Blackmun from Jenness v. Fortson (1971) (on file in the papers of Harry A. Blackmun, Box 131). The Chief Justice declared that the 
One year later, in a primary ballot access case, the Court raised its scrutiny level again. In Bullock v. Carter, ${ }^{198}$ after weighing whether to apply rational basis or a "more rigid standard of review," the Court "closely scrutinized" Texas' filing fee provisions. ${ }^{199}$ The Court tested whether the provisions were "reasonably necessary to the accomplishment of legitimate state objectives" because the fee had "a real and appreciable impact on the exercise of the franchise, and because this impact [was] related to the resources of the voters supporting a particular candidate . . ."200 Although the opinion was unanimous, this unanimity belied the Justices' differences at conference.

Chief Justice Burger openly asked "How far do we go[?]," while Justice Brennan indicated that the case was a "Straight 1[st] Amendment" case, though Justice Stewart preferred equal protection grounds. ${ }^{201}$ Justice Blackmun's notes are most telling, seemingly deciding between the rationales used in the Williams opinion and concurrences, he queried, "1[st] $\mathrm{A}[$ mendment $]$ - $\mathrm{D}$ [ue] $\mathrm{P}$ [rocess] - E[qual] $\mathrm{P}$ [rotection]?" $202 \mathrm{He}$ also wrote to himself, "I have no great interest as to whether we affirm on equal protection or First Amendment grounds, but I think each and all of them has application here. Williams v. Rhoades [sic] is controlling." ${ }^{203}$ The Court was clearly struggling with the doctrine.

Two years after Bullock, the Court decided Storer v. Brown ${ }^{204}$ and American Party v. White. $^{205}$ In both cases, the Court struggled with the doctrine, performing an equal

case was "distinguishable from W[illiams] v. R[hodes]. 5\% [is] n[ot] an undue burden." Id. Justice Douglas explained, "W[illiams] v. R[hodes] is t[he] totality v. t[he] sep[arate provisions] on this record." Id. Justice Stewart described the Georgia system as "Very free. Free [to] write in." Id. For his own part, Justice Blackmun thought the First Amendment rationales were weak. In a memorandum, he wrote: "This case is a necessary supplement to Williams v. Rhodes .... [The Socialist Workers Party] claim[s] that conditions are too stringent and, hence, that their First Amendment rights are violated. I am not persuaded by this. // I think the equal protection argument is a much better one. It was one which prevailed in Ohio. . . The problem is where to draw the line. .. . The Court in Williams v. Rhodes drew the line where it did on a combination of circumstances. Here we are confronted more with simple numbers." Id.

${ }^{198}$ Bullock v. Carter, 405 U.S. 134 (1972).

${ }^{199} \mathrm{Id}$. at 142 .

${ }^{200}$ Id. at 144; see Smith, supra note 2, at 199-201 (describing and criticizing the Court's conclusions on ballot access laws and filing fees from Williams to Bullock).

${ }^{201}$ Conference Notes of Justice Harry A. Blackmun from Bullock v. Carter (1971) (on file in the papers of Harry A. Blackmun, Box 141).

${ }^{202} \mathrm{Id}$.

${ }^{203}$ Memorandum from Justice Harry A. Blackmun to himself (Nov. 16, 1971) (on file in the papers of Harry A. Blackmun, Box 141).

${ }^{204}$ Storer v. Brown, 415 U.S. 724 (1974). California forbade independent candidates who voted in the immediately preceding primary or were registered for one year prior to that primary with a political party. Id. at 726 .

${ }^{205}$ American Party v. White, 415 U.S. 767 (1974). Texas provided four methods of ballot access, including automatic access for major parties, state convention nominations, precinct convention and petition nominations, and independent petition. Id. at 772-75. 
protection inquiry and using the language of strict scrutiny but not applying it. ${ }^{206}$ In a memorandum to himself, Blackmun wrote, "as in the following Texas case, we have an initial standard of review to determine and apply. Is the statute to be viewed in the totality of the circumstances? Or, in contrast, is it to be viewed provision by provision? This is the contrast between Williams v. Rhodes and Jenness v. Fortson." ${ }^{207}$ He continued, outlining the jurisprudential difficulty the Court faced in reconciling its precedent and real-world application: "Totality was applied in [Williams] and individuality in [Jenness], without much stated relationship between the two. Sometimes either approach brings us out at the same point. On other occasions that result is not necessarily assured." 208 In Storer, the Justices debated the connections of the cases with Williams and Jenness and discussed whether to affirm or remand. ${ }^{209}$ Ultimately the Court, in Storer, noted that the totality of the laws was not in question, as the specific disaffiliation provision challenged was constitutional whether in combination or independent from other California ballot access laws. It concluded, "The disaffiliation requirement does not change its character when combined with other provisions of the electoral code. It is an absolute bar to candidacy, and a valid one." ${ }^{210}$ Settling on an intermediate level of scrutiny unconcerned with predictability, the Court wrote:

It is very unlikely that all or even a large portion of the state election laws would fail to pass muster under our cases; and the rule fashioned by the Court to pass on constitutional challenges to specific provisions of election laws provides no litmus-paper test for separating those restrictions that are valid from those that are invidious under the Equal Protection Clause. The rule is not self-executing and is no substitute for the hard judgments that must be made. Decision in this context, as in others, is very much a 'matter of degree,' much a matter of 'consider(ing) the facts and circumstances behind the law, the interests which the State claims to be

\footnotetext{
${ }^{206}$ Smith, supra note 2, at 188 ("[A]lthough the Court found a compelling state interest . . . it did not inquire into whether less drastic means were available to the state to serve that interest. Implicit in this approach is a standard of review significantly less demanding than traditional strict scrutiny."); Smith, supra note 2, at 189 ("As in Storer, the Court [in White] found compelling state interests, but did not engage in a least restrictive alternative analysis."); Leonard P. Stark, You Gotta Be On It to Be In It: State Ballot Access Laws and Presidential Primaries, 5 GEO. MASON L. REV. 137, 143-44 (1996); Zywicki, supra note 24, at 114 .

${ }^{207}$ Memorandum from Justice Harry A. Blackmun to himself (Nov. 5, 1973) (on file in the papers of Harry A. Blackmun, Box 175).

${ }^{208} \mathrm{Id}$.

${ }^{209}$ The Chief Justice noted that the "Cal[ifornian] stat[ute] [was] n[ot] unduly exclusionary u[nder] the totality rule of Williams," while the dissenters-Justices Douglas, Marshall, and Brennan-said it was "nearer Williams [than] Jenness." Conference Notes of Justice Harry A. Blackmun (Nov. 7, 1973) (on file in the papers of Harry A. Blackmun, Box 175). Justice Blackmun concluded that the totality approach was applicable and provided no reason for reversal. Memorandum from Justice Harry A. Blackmun, supra note 207.

${ }^{210}$ Storer v. Brown, 415 U.S. 724, 737 (1974).
} 
protecting, and the interests of those who are disadvantaged by the classification.' What the result of this process will be in any specific case may be very difficult to predict with great assurance. ${ }^{211}$

In addition, a Blackmun memorandum illustrates the internal deliberations between using equal protection or First Amendment grounds and the Court's, or at least the Justice's, concern with the reasoning, he wrote:

Ben [Sharp, law clerk] has pointed out that the approach through the First Amendment is far preferable than through equal protection under the Fourteenth. I am inclined to agree that the appellants have an easier way conceptually through the First Amendment. I suppose we must shadowbox with talk about compelling state interest or rationality. ${ }^{212}$

In American Party v. White, the Court applied this same "shadowbox" scrutiny and analysis:

[W]hether the qualifications for ballot position are viewed as substantial burdens on the right to associate or as discriminations against parties not polling $2 \%$ of the last election vote, their validity depends upon whether they are necessary to further compelling state interests. . . [W]e also agree with the District Court that the foregoing limitations, whether considered alone or in combination, are constitutionally valid measures, reasonably taken in pursuit of vital state objectives that cannot be served equally well in significantly less burdensome ways. ${ }^{213}$

Justice Douglas dissented from the majority's cursory finding that the provisions were valid under a totality or individual approach. He noted that the totality of the circumstances amounted to invidious discrimination. ${ }^{214}$ Justice Blackmun, who joined the majority, seemed to have, at one point, agreed with Douglas. Blackmun wrote in his own notes that under a totality test the case should be reversed. ${ }^{215}$ He mused: "The difficulty, of course, is the conceptual or philosophic one. Should we decide each new election case

${ }^{211}$ Id. at 731 .

${ }^{212}$ Memorandum from Justice Harry A. Blackmun, supra note 207, at 5. This view contrasts his thoughts in Jenness. See Notes of Justice Harry A. Blackmun, supra note 197.

${ }^{213}$ American Party v. White, 415 U.S. 767, 780-81 (1974) (internal citation omitted).

${ }^{214}$ American Party, 415 U.S. at 797 (Douglas, J., dissenting).

${ }^{215}$ Notes of Justice Harry A. Blackmun from American Party v. White (1973) (on file in the papers of Harry A. Blackmun, Box 176). 
on a totality of circumstances approach or on a dissection analysis[?]"216 He tellingly guessed that, "Perhaps there is a third and better method, but I have not, as yet, uncovered it." ${ }^{, 217}$ He also previewed a shift in rationales, noting that he "could go along with [a First Amendment approach] if a majority of the Court are so inclined." 218 Although these cases suggest some convergence toward intermediate scrutiny masked in strict scrutiny language, the Court shifted gears yet again five years later.

In 1979, the Court returned to traditional strict scrutiny analysis. Justice Marshall, in Illinois State Board of Elections v. Socialist Workers Party, ${ }^{219}$ applied the Equal Protection Clause, used strict scrutiny, and invalidated the Illinois Election Code, which required new political parties and independent candidates to obtain five percent of the electorate's signatures for that same position in the preceding election. ${ }^{220}$ In conference, Justice Brennan laid out the conceptual discussion, while Stewart determined the decision should be based on equal protection, both positions with which Justices Marshall, Powell, and Stevens agreed. ${ }^{221}$ More revealing than the conference is Justice Blackmun's short concurrence, in which he decries the Court's scrutiny level and precedent. It shows Blackmun's internal struggle in the prior cases coming to the fore and is significant, given that the Court would soon shift tests. It is reproduced in its entirety:

Although I join the Court's opinion and its strict-scrutiny approach for election cases, I add these comments to record purposefully, and perhaps somewhat belatedly, my unrelieved discomfort with what seems to be a continuing tendency in this Court to use as tests such easy phrases as "compelling [state] interest" and "least drastic [or restrictive] means." I have never been able fully to appreciate just what a "compelling state interest" is. If it means "convincingly controlling," or "incapable of being overcome" upon any balancing process, then, of course, the test merely announces an inevitable result, and the test is no test at all. And, for me, "least drastic means" is a slippery slope and also the signal of the result the Court has chosen to reach. A judge would be unimaginative indeed if he could not come up with something a little less "drastic" or a little less "restrictive" in almost any situation, and thereby enable himself to vote to strike legislation down. This is reminiscent of the Court's indulgence, a

${ }^{216}$ Memorandum from Justice Harry A. Blackmun to himself (Oct. 31, 1973) (on file in the papers of Harry A. Blackmun, Box 176).

${ }^{217} \mathrm{Id}$.

${ }^{218} I d$. at 3 . Justice Blackmun then oddly wrote, given his focus on the totality of the laws, that "if we reverse, we should reverse specific sections of the Texas election code." Id.

${ }^{219}$ Ill. State Bd. of Elections v. Socialist Workers Party, 440 U.S. 173 (1979).

${ }^{220}$ Id. See Kurt Wittenberg, Recent Cases, Anderson v. Celebrezze: Ballot Access and the Due Process Clause - An Alternative to Equal Protection Analysis, 33 DePaul L. Rev. 411, 416 (1983); Stark, supra note 206, at 145; Zywicki, supra note 24, at 111.

${ }^{221}$ Conference Notes of Justice Harry A. Blackmun from Ill. State Bd. of Elections v. Socialist Workers Party (Nov. 8, 1978) (on file in the papers of Harry A. Blackmun, Box 284). 
few decades ago, in substantive due process in the economic area as a means of nullification.

I feel, therefore, and have always felt, that these phrases are really not very helpful for constitutional analysis. They are too convenient and result oriented, and I must endeavor to disassociate myself from them. Apart from their use, however, the result the Court reaches here is the correct one. It is with these reservations that I join the Court's opinion. ${ }^{222}$

This string of cases outlines the Court's first struggle after Williams. In this period, the Court applied different standards and scrutiny levels and examined cases either in their totality or provision-by-provision, based upon the case's particulars. Indeed, in Clements v. Flashing, ${ }^{223}$ the Court noted that the constitutional question is a matter of degree and facts (suggesting a totality of the circumstances approach) while also concluding that "[n]ot all ballot access restrictions require 'heightened' equal protection scrutiny." ${ }^{224}$ In so doing, the Court produced a complex web of jurisprudence. Overturning no case, results became unpredictable, unmooring the underlying constitutional anchor of the Equal Protection Clause. Then, in the midst of this struggle for coherence, the Court shifted gears and abandoned the Equal Protection Clause as a reservoir for the rights at issue. The next section explores the shift from the Equal Protection Clause to the First Amendment and the Court's ongoing search for a standard.

\section{B. The Struggle Continues: It's All About Balance - From Anderson to Today}

The Court's decision in Anderson v. Celebrezze revised the Court's jurisprudence, resting its decision on the First Amendment, as made applicable to the states by the Fourteenth, rather than the Equal Protection Clause, and substituted a balancing test for strict scrutiny. ${ }^{225}$ The Court, however, relied on past equal protection analyses, suggesting a framework, rather than a rationale shift. Indeed, the Court makes it clear that the source of the scrutiny requirement-equal protection or political speech and association-makes no jurisprudential difference. ${ }^{226}$ The case concerned John

${ }^{222}$ Socialist Workers Party, 440 U.S. at 188-89 (Blackmun, J., concurring).

${ }^{223}$ Clements v. Flashing, 457 U.S. 957 (1982).

${ }^{224}$ Id. at $963,966-67$.

${ }^{225}$ Anderson v. Celebrezze, 460 U.S. 780,786 n.7 (1983).

${ }^{226} I d$. ("In this case, we base our conclusions directly on the First and Fourteenth Amendments and do not engage in a separate Equal Protection Clause analysis. We rely, however, on the analysis in a number of our prior election cases resting on the Equal Protection Clause of the Fourteenth Amendment. These cases, applying the "fundamental rights" strand of equal protection analysis, have identified the First and Fourteenth Amendment rights implicated by restrictions on the eligibility of voters and candidates, and have considered the degree to which the State's restrictions further legitimate state interests.”). 
Anderson's independent candidacy for the Presidency. Unable to appear on the ballot because of Ohio's early filing deadline, he brought suit, and the Court invalidated the provision. $^{227}$ Justice Stevens laid out the test and its implications:

[A Court] must first consider the character and magnitude of the asserted injury to the rights protected by the First and Fourteenth Amendments that the plaintiff seeks to vindicate. It then must identify and evaluate the precise interests put forward by the State as justifications for the burden imposed by its rule. In passing judgment, the Court must not only determine the legitimacy and strength of each of those interests; it also must consider the extent to which those interests make it necessary to burden the plaintiff's rights. Only after weighing all these factors is the reviewing court in a position to decide whether the challenged provision is unconstitutional. ... The results of this evaluation will not be automatic; as we have recognized, there is "no substitute for the hard judgments that must be made." 228

Conference notes from Justice Blackmun indicate that the Justices debated the level of scrutiny to be applied and the Equal Protection Clause's applicability. Justice White noted that the Court "w[oul]d get sa[me] result on E[qual] $\mathrm{P}$ [rotection] [as] on 1A[the First Amendment]," while Justice Brennan noted that "strict scrutiny is it" and that the "deadline has to fall, even assuming voter education is a compelling int[erest]." "229 Justice Rehnquist said that "strict scrutiny is judicial puppetry," while Justice Stevens declared the deadline "totally irrational," and, in a preview of his balancing test, stressed the effects on major parties, independents, candidates, and voters. ${ }^{230}$ Justice Blackmun, in private notes, wrote, "If rationality, O[hio]'s int[erest]s, tho[ugh] tenuous, [a]r[e] prob[ably] suff[icient]. If strict scrutiny, the] deadline must fall."231 The Court's struggle with the scrutiny to be applied is significant given that it abandoned the doctrine for a balancing test, which it subsequently confirmed, abandoned again, and then attempted to reconcile with its overall jurisprudence.

In 1986, the Court used the Anderson balancing test in Munro v. Socialist Workers Party but did so a priori, noting that the State of Washington would not need to prove the ills it sought to combat. ${ }^{232}$ The Court held constitutional a Washington statute requiring minor-party candidates to receive at least one percent of all votes cast for that office in a primary election before gaining access to the general election ballot under the First and

${ }^{227}$ Id. at 782. As a result of Williams, Anderson only needed 14,500 signatures for his nominating petition. Id. at 782, 784-85.

${ }^{228}$ Anderson, 460 U.S. at 789-90 (internal citations omitted).

${ }^{229}$ Conference Notes of Justice Harry A. Blackmun from Anderson v. Celebrezze (Dec. 8, 1982) (on file in the papers of Harry A. Blackmun, Box 377).

${ }^{230} \mathrm{Id}$.

${ }^{231} I d$

${ }^{232}$ See Munro v. Socialist Workers Party, 479 U.S. 189, 194-95 (1986). 
Fourteenth Amendments. ${ }^{233}$ The opinion explicitly noted that strict scrutiny may apply, as it did in Williams, but that the rights to political association and to cast one's vote effectively were not absolute and could be conditioned by states, and that no "litmus-paper test" existed to decide such cases. ${ }^{234}$ The opinion stressed that the facts presented were much less restrictive than the provisions upheld in Jenness and American White Party. ${ }^{235}$ The Court, therefore, simply placed Washington's provisions on a spectrum, found them to be less egregious than other provisions upheld, and ruled the laws constitutional under the First Amendment. ${ }^{236}$ Conference notes suggest that the Justices, echoing Justice's Blackmun's concurrence in Illinois State Board of Elections, were beginning to chafe under the accumulated precedent, as any result under any standard seemed possible. ${ }^{237}$

In 1992, the Court again confirmed the Anderson test, but not before a familiar detour into strict scrutiny, implying that the balancing test did not replace previous tests and standards; rather, it added to them. Justice Souter, in Norman v. Reed, ${ }^{238}$ applied strict scrutiny for a seven-member majority and invalidated an Illinois law requiring new parties to gather a substantial number of signatures for ballot access. ${ }^{239}$ The Court confirmed its abandonment of the Equal Protection Clause and utilized strict scrutiny analysis, not the balancing test Anderson propounded, although it never used the phrase "strict scrutiny."

Six months later, the Court, in Burdick v. Takushi, ${ }^{240}$ attempted to reconcile and define the lines between strict scrutiny and its balancing test. Justice White held:

[A] more flexible standard applies. A court considering a challenge to a state election law must weigh "the character and magnitude of the asserted injury to the rights protected by the First and Fourteenth Amendments that the plaintiff seeks to vindicate" against "the precise interests put forward by the State as justifications for the burden imposed by its rule," taking into consideration "the extent to which those interests make it necessary to burden the plaintiff's rights."

${ }^{233} I d$.

${ }^{234}$ Id. at 193.

${ }^{235}$ Id. at $194-95$.

${ }^{236} \mathrm{Id}$. at 199.

${ }^{237}$ Chief Justice Rehnquist noted that the Court's ballot access cases had "little analytical content" and the jurisprudence was "ad hoc," while Justice O'Connor described the precedent as in "disarray" with the Court applying a "mid-level scrutiny." Conference Notes of Justice Harry A. Blackmun from Munro v. Socialist Workers Party (Oct. 10, 1986) (on file in the papers of Harry A. Blackmun, Box 284).

${ }^{238}$ Norman v. Reed, 502 U.S. 279 (1992).

${ }^{239}$ Id. at 280, 289-90; Porto, supra note 65, at 304; Stark, supra note 206, at 147. Justice Blackmun's conference notes do not contain anything revealing about the Court's deliberations here.

${ }^{240}$ Burdick v. Takushi, 504 U.S. 428 (1992). 
Under this standard, the rigorousness of our inquiry into the propriety of a state election law depends upon the extent to which a challenged regulation burdens First and Fourteenth Amendment rights. Thus, as we have recognized when those rights are subjected to "severe" restrictions, the regulation must be "narrowly drawn to advance a state interest of compelling importance." But when a state election law provision imposes only "reasonable, nondiscriminatory restrictions" upon the First and Fourteenth Amendment rights of voters, "the State's important regulatory interests are generally sufficient to justify" the restrictions. We apply this standard in considering petitioner's challenge to Hawaii's ban on write-in ballots. $^{241}$

The Court upheld Hawaii's prohibition of write-in voting because of a relaxed primary ballot access regime and rejected the claim that strict scrutiny applies. ${ }^{242}$ At conference, the Justices focused on which test to use. Chief Justice Rehnquist again noted that the "area holdings are ad hoc," a sentiment Justice Scalia echoed. ${ }^{243}$ The Chief, Justice O'Connor, and the author of Norman, Justice Souter, all mentioned that the case should be treated as a ballot access case, while Justice O'Connor explicitly stated that Anderson, and not Norman, was the standard. ${ }^{244}$ As demonstrated below, this dispute continues to remain a source of confusion and conflict.

So the Court has left us with a test that balances its own jurisprudence, by categorizing its dueling levels of scrutiny by the burdens brought to the Court. ${ }^{245}$ Burdick did not simply reaffirm the Anderson balancing test, as Zywicki suggests, ${ }^{246}$ rather it was reformed with old strains from Williams and others still present. ${ }^{247}$ The Court, through detours and roundabouts, left dueling standards and rationales in place to determine which level of scrutiny to apply and whether to take a totality approach. From this inquiry, it is clear why Zywicki would characterize the Court's efforts as "largely resultsbased, with legal doctrine following as post hoc rationalizations for decisions already reached. [For w] hen the Court applies heightened scrutiny, it seemingly does so only after determining that the regulations in question are especially draconian. ${ }^{, 248}$ As this Note has demonstrated, this criticism has its genesis in Williams, where the Court, under

${ }^{241} I d$. at 434 (internal citations omitted).

${ }^{242} I d$. at 428 .

${ }^{243}$ Conference notes of Justice Harry A. Blackmun from Burdick v. Takushi (Mar. 27, 1992) (on file in the papers of Harry A. Blackmun, Box 600).

${ }^{244} I d$.

${ }^{245}$ Professors Dimino, Smith, and Solimine call the current test a "sliding scale, with the level of scrutiny varying depending on the extent of the burden on constitutional rights." MICHAEL DIMINO ET AL., VOTING RIGHTS AND ELECTION LAW 556 (2010).

${ }^{246}$ Zywicki, supra note 24, at 116.

${ }^{247}$ See Stark, supra note 206, at 147-48; Walstra, supra note 34, at 118; see also Crawford v. Marion Cnty. Election Bd., 553 U.S. 181 (2008) (citing Anderson and Burdick among other cases, the Justices engage in a spirited debate about the standard and scrutiny level to be applied in a voter identification case).

${ }^{248}$ Zywicki, supra note 24, at 108. 
political pressure and with the plainly anti-democratic regime of Ohio before it, simultaneously freed Wallace from Ohio's impinging laws and crafted a doctrinal quagmire.

\section{Modern Application: Perry v. Judd}

A recent District Court case from January 2012 illustrates the Court's dueling standards at work. ${ }^{249}$ In Perry v. Judd, plaintiff Rick Perry and intervenors challenged Virginia's statutory requirement that statewide candidates obtain 10,000 signatures, including 400 from each congressional district, to appear on the ballot. ${ }^{250}$ Judge Gibney denied the plaintiffs relief under laches. ${ }^{251}$ However, he also examined the merits of the 10,000 -signature requirement and found it valid. ${ }^{252}$

Judge Gibney, citing the pre-Anderson case Storer, condensed the ballot access jurisprudence to one question: "[W]hether, given the totality of the circumstances, a reasonably diligent candidate could be expected to meet the signature requirement or whether the statute is excessively burdensome." ${ }^{, 53}$ Then, tracing a long line of precedent where signature requirements were upheld from Storer, American White Party, and Jenness to lower court rulings, Judge Gibney found that the 10,000 signature requirement representing $0.2 \%$ of Virginia's voters or $0.5 \%$ of voters at the last statewide election was minimal and not unduly burdensome, especially since six candidates made the ballot in 2008. ${ }^{254}$ Judge Gibney, relying on Buckley v. American Constitutional Law Foundation,

${ }^{249}$ Another illustrative Supreme Court case, Timmons v. Twin Cities Area New Party, shows the Court splitting its two tests and applying the Anderson strain to uphold Minnesota's ban on fusion candidacies. 520 U.S. 351, 370 (1997). Finding that the ban, which prevents different parties from nominating the same candidate, did not severely interfere with New Party's political activities, the Court determined the ban was not severe. Id. at 363-64. The Court also affirmed a state interest in favoring the two-party system, which Williams roundly rejected. Id. at 367; Williams v. Rhodes, 393 U.S. 23, 32 ("T] merely favor a 'two-party system'; it favors two particular parties - the Republicans and the Democrats and .... There is ... no reason why two parties should retain a permanent monopoly on the right to have people vote for or against them."). New Party, therefore, calls much of ballot access jurisprudence into question; if a state can ban fusion candidates to promote the two-party system, Ohio's 1968 scheme should stand. Although beyond the scope of this Note, a solution to this doctrinal landmine is necessary. Perhaps the two-party interest should remain, but be limited and unavailable to schemes that ensconce the Democratic and Republican parties, like Ohio's. Perhaps the rationale should be reconsidered and rejected. An answer requires careful analysis of permissible and impermissible state interests. Whatever the solution, it is clear that New Party questions the burdens a state can impose on third parties seeking ballot access.

${ }^{250}$ Perry v. Judd, 840 F. Supp. 2d. 945, 950 (E.D. Va. 2012).

${ }^{251} I d$. at 953 .

${ }^{252} \mathrm{Id}$. at 960 .

${ }^{253}$ Id. at 959 .

${ }^{254}$ Id. 
also found that a residency requirement for petition circulators would likely be unconstitutional. ${ }^{255}$

In addition, the Court performed brief strict and rational basis scrutiny analyses at the plaintiffs' urging. Judge Gibney first found that the 10,000-signature requirement was not unduly burdensome and warranted only rational basis scrutiny. He found Virginia's interest in ensuring a fair and orderly election, as well as its interest in keeping frivolous candidates from the ballot, sufficient justification for the signature requirement. ${ }^{256}$ These interests, confirmed in Jenness, represent the permissible rationales for state control of the ballot. As long as they do not create a two-party monopoly or act as pretext for other impermissible ends as Justice Black first noted in Williams, the restrictions will stand. ${ }^{257}$ Judge Gibney also noted, without further explanation, that Virginia's requirement would survive strict scrutiny analysis. ${ }^{258}$ Judge Gibney reached these separate issues at plaintiffs' request, which was warranted under the Court's confusing precedent.

This recent case shows how each of the dueling standards the Court has left in place since Williams and Anderson requires application in ballot access litigation. One commentator aptly synthesized the standards that remain:

The Court takes the balancing approach found in Anderson and separates voters' injuries into two categories: severe and reasonable. Accordingly, the key decision a court must make is whether the election law reasonably restricts the rights of voters or candidates. If the restriction is reasonable, then the law is likely valid. If the restriction is unreasonable and considered severe, then the law is subject to strict scrutiny, and the court will likely find it unconstitutional. ${ }^{259}$

This amalgamated standard is essentially a combination of the Anderson test and the Williams and Norman tests, with the former taking precedence. It is a question of scrutiny level without regard to the source of the requirement, be it equal protection as Williams envisioned, or political speech and association as Anderson established. Here, the district court performed both the Anderson and Norman tests upon the facts before it. At a minimum, this implicates judicial efficiency, uniformity, and predictability. The two tests either require a district court judge to pick one or the other, or as here, apply both. Without instruction from the Supreme Court, which test to apply is a matter of judicial guesswork. The former results in variable rulings, while the latter, in extreme cases, can needlessly consume judicial resources or at least inconvenience courts.

${ }^{255} \mathrm{Id}$. at $956-58$.

${ }^{256} I d$. at 959 n. 10.

${ }^{257}$ See supra Part IV.

${ }^{258}$ Perry, 840 F. Supp. 2 d at 959 n. 10.

${ }^{259}$ Walstra, supra note 34, at 118-19; see also Crawford v. Marion Cnty. Election Bd., 553 U.S. 181 (2008) (citing Anderson and Burdick, among other cases, the Justices engaged in a spirited debate about the standard and scrutiny level to be applied in a voter identification case). 
Although Perry v. Judd was a simple case on the facts, more complicated provisions could result in split decisions, where the Anderson test produces one conclusion and a Norman analysis the opposite. This scenario is not unimaginable. Indeed, in Perry v. Judd, the district court could have taken the petition requirement into account in determining that the signature requirement, under a totality of the circumstances, impermissibly burdened voters' rights, while simultaneously finding that a rational basis analysis would uphold the laws. Similar conclusions would leave courts torn and potentially result in intellectually discordant decisions, with judges bending logic or the tests in order to reach a consonant result under both standards.

More troubling than arguments of judicial efficiency, confusion, or discordance is the point Professor Zywicki makes, which is that judges seem first to conclude whether restrictions should stand and then apply either test to reach the desired result. This practice leaves the realm of ballot access jurisprudence to judicial intuition, an inconsistent and insufficient guardian of core democratic rights. Enabling judges to pick either test to reach a conclusion or forcing the application of two tests resulting in antipodal conclusions hardly serves the interests of justice or develops legal coherency.

\section{Toward a Solution}

Unfortunately, no easy solution presents itself. As mentioned earlier, Professor Zywicki argues for a return of ballot access regulation to the states ${ }^{260}$ and Professor Bradley Smith calls for strict scrutiny analysis in all cases. ${ }^{261}$ These opposing solutions both have the benefit of clarity. This Note posits that the best solution, both legally sound and historically accurate, is a reassertion of the Anderson test accompanied by an explicit rejection of strict scrutiny analysis.

This solution would mean a repudiation of those parts of Williams, Norman, Munro, Jenness, Bullock, Storer, American Party, Clements, and Socialist Workers Party that: i) rely on the Equal Protection Clause, ii) call for any sort of scrutiny analysis, be it rational basis, intermediate, or strict, or iii) examine provisions in isolation rather than under the totality of the circumstances. Rejecting these lingering strains of judicial analysis and focusing on one test will eliminate the problem of ad hoc, result-based judicial rationalization. Eliminating judicial intuition and applying the Anderson test will over time create a coherent doctrine that both protects voters and enables necessary state regulation.

Furthermore, a balancing approach that examines the entire statutory scheme in question as in Burdick, remains faithful to the Justices' concerns in Williams without slavishly following failed precedent. While Williams' standard proved too rigid, it importantly widened the scope of judicial inquiry to encompass the totality of the

\footnotetext{
${ }^{260}$ Zywicki, supra note 24, at 133.

${ }^{261}$ Smith, supra note 2, at 168.
} 
infringing provisions. As illustrated above, this became a major concern for the Justices after Williams. The proposed test, in effect, applies the best parts of Williams while jettisoning its worst aspects. In so doing, the Anderson standard discards the predictability of a rule and Williams' equal protection basis. However, it keeps Williams' concern for the First Amendment rights of voters, as first demonstrated during the Justices' Conference in October 1968, ${ }^{262}$ and its indignation at Ohio's rules at its base. This test also maintains Williams' singular focus on the totality of the restrictions at issue, as demonstrated in both Black and Douglas' opinions. This test essentially embraces the framework Douglas posited in concurrence without its absolutist results.

This test also maintains judicial flexibility to ensure that states can legitimately regulate elections without "unnecessarily burden[ing] the availability of political opportunity," 263 which the Court struggled to do in the wake of Williams. Under this framework, the Court could remain focused on the fundamental rights Williams identified and the context of the restrictions, while maintaining flexibility for state regulation, increasing judicial uniformity and efficiency, and providing clarity to lower courts. This test finds support in the Justices' papers, both in Williams and beyond, ${ }^{264}$ and offers a solution to the central problem of ballot-access jurisprudence, namely: how to balance the state's legitimate needs with the most necessary of democratic acts, voting. In shedding a portion of Williams, this test remains faithful to the spirit of that opinion, protects the necessity of state regulation of the ballot, ensures voter rights, and provides a clear blueprint to trial judges.

\section{CONCLUSION}

In October 1968, the Court faced a novel legal question with political and historical implications. In forging an answer, the Justices confronted a febrile political environment, which generated intense pressure upon the Court. Governor Wallace's strong campaign and Ohio's ballot access laws dictated the Williams result. Ohio's disqualifying laws, which excluded third-party and independent candidates in form and function, demonstrated its determination to maintain major party dominance. Court documents reveal the Justices' thinking and provide context and color to the decision, showing discarded doctrines and arguments.

In the end, the Court swept the laws aside in their totality, invalidating the Ohio regime and placing Wallace on the ballot. Williams was right on the merits, wrong on the

262 See supra Part III.

${ }^{263}$ Clements v. Flashing, 457 U.S. 957, 964 (1982) (internal quotation marks omitted).

${ }^{264}$ See, Conference Notes of Justice William O. Douglas, supra note 93; Memorandum from Justice Harry A. Blackmun to himself, supra note 203; Memorandum from Justice Harry A. Blackmun to himself, supra note 207; Notes of Justice Harry A. Blackmun from American Party v. White, supra note 215; Memorandum from Justice Harry A. Blackmun to himself, supra note 216; Conference Notes of Justice Harry A. Blackmun from Anderson v. Celebrezze, supra note 229; Conference notes of Justice Harry A. Blackmun from Burdick v. Takushi, supra note 243; see also Williams, 393 U.S. at 30; Anderson, 460 U.S. at 789-90 (internal citations omitted). 
doctrine; it generated a doctrinal cul-de-sac, which the Court is still trying to exit and straighten. In the decades that followed, despite new Justices and numerous opinions and factual developments, the Court has yet to create coherence from or reconcile its first foray into ballot access law. As a result, ballot access jurisprudence is overly complicated and uncertain. By declaring the Anderson test, which balances the competing interests at stake under an incorporated First Amendment framework, the sole standard, the Court could stay true to Williams' concerns while eliminating the many ills and confused jurisprudence that linger today.

E. Jon A. Gryskiewicz•

- JD/MA candidate, University of Virginia. I would like to convey my heartfelt gratitude to Professor Charles McCurdy for guiding me through the process of archival research and for his suggestions during the planning, development, and writing of this Note. I would also like to express my deep appreciation to Professor George Rutherglen for helping me decipher Justice Douglas' handwriting and to Professor John Harrison for his valuable comments. In addition, I would like to thank Professors Risa Goluboff and G. Edward White for their thoughtful suggestions on earlier drafts. I would also like to extend my appreciation to the Editors of the Journal of Law and Politics, the American Legal History Seminar participants, and the Legal History Workshop attendees for their assistance and helpful contributions. Special thanks should be given to the Library of Congress and Justice Black's estate for providing me access to Justice Black's papers. Finally, I am indebted to my family, especially my mother, for their countless hours of edits and encouragement during this project. 
Appendix I: Signature Requirements for Ballot Access by Petition by State, 1968

\begin{tabular}{|c|c|c|}
\hline State & Total & Percentage \\
\hline AK & 1,000 & \\
\hline AL & 300 & \\
\hline AR & 84,529 & 15 of G \\
\hline AZ & 9,680 & 2 of $\mathrm{G}$ \\
\hline CA & 352,879 & 5 of GE \\
\hline CO & 300 & \\
\hline CT & 4,131 & 0.5 of $\mathrm{LSC}$ \\
\hline GA & 98,022 & 5 of $\mathrm{RV}$ \\
\hline HI & 25 & \\
\hline IA & 1,000 & \\
\hline ID & 3,000 & \\
\hline IL & 25,500 & \\
\hline IN & 8,320 & .5 of $\mathrm{SS}$ \\
\hline KS & 34,647 & 5 of $\mathrm{G}$ \\
\hline KY & 1,000 & \\
\hline MA & 61,235 & 3 of G \\
\hline MD & 5,000 & \\
\hline ME & 3,238 & 1 of G \\
\hline MN & 2,000 & \\
\hline MO & 18,095 & 1 of $\mathrm{NG}$ \\
\hline MS & 10,000 & \\
\hline MT & 8,212 & 5 of $\mathrm{LSC}$ \\
\hline
\end{tabular}

\begin{tabular}{|c|c|c|}
\hline State & Total & Percentage \\
\hline NC & 337,306 & 25 of $\mathrm{G}$ \\
\hline ND & 15,000 & \\
\hline NE & 1,000 & \\
\hline NH & 1,000 & \\
\hline NJ & 800 & \\
\hline NV & 6,393 & 5 of $\mathrm{RC}$ \\
\hline NY & 12,000 & \\
\hline OH & 433,100 & 15 of $\mathrm{G}$ \\
\hline OK & 5,000 & \\
\hline OR & 4,474 & 3 of $\mathrm{RC}$ \\
\hline PA & 10,552 & .5 of $\mathrm{ASW}$ \\
\hline RI & 500 & \\
\hline SC & 10,000 & \\
\hline SD & 4,564 & 2 of $\mathrm{I}$ \\
\hline TN & 25 & \\
\hline TX & 14,259 & 1 of G \\
\hline UT & 500 & \\
\hline VA & 250 & \\
\hline VT & 1,363 & 1 of G \\
\hline WI & 3,000 & \\
\hline WV & 7,920 & 1 of GE \\
\hline WY & 100 & \\
\hline & & \\
\hline
\end{tabular}




\begin{tabular}{|c|c|}
\hline Abbreviation & Percentage of Votes Cast \\
\hline ASW & For Any Successful State-Wide Candidate \\
\hline G & In Last Gubernatorial Election \\
\hline GE & In Last General Election \\
\hline LSC & For Last Successful Candidate for Same Office \\
\hline NG & In Next General Election \\
\hline RC & For Last Successful Representative for Congress \\
\hline RV & Of Registered Voters \\
\hline SS & In Last Election for Secretary of State \\
\hline
\end{tabular}

State percentage requirements were often based upon particular elections. For a comprehensive breakdown of the system, as it stood in 1968, see Elections - Equal Protection, supra note 85 . The key explains the percentage requirements above. For Pennsylvania, the data assumes the lowest successful statewide candidate was Governor Raymond Shafer in 1966. 